\title{
EL DERECHO INTERNACIONAL PENAL Y LA JUSTICIA PENAL INTERNACIONAL EN EL TERCER MILENIO
}

\author{
Juan Carlos VeLÁZqUEZ ELIZARRARÁs*
}

RESUMEN: El derecho internacional que se manifiesta a través de su rama penal cobra hoy enorme relevancia porque vivimos en el contexto de una sociedad global de características conflictuales y patológicas, donde imperan la violencia, el caos y el desorden, la inseguridad, el demérito de los valores, las conductas delictuosas, los crímenes y las formas de organización internacional criminal, las infracciones a la ley y la impunidad en todas sus acepciones. En este artículo, el autor presenta el primer acercamiento a lo que él denomina "un nuevo enfoque teórico-conceptual del derecho internacional penal". En donde juega un papel importante la justicia penal internacional a través de la Corte Penal Internacional.
ABSTRACT: International law, manifested in its criminal branch, has aquired today mayor relevance because we live in the context of a global society, of conflictive and pathological characteristics, ruled by violence, chaos and disorder, insecurity, the disregard for values, unlawful conducts, crime and international criminal organisations, the breach of law, and impunity in each of its interpretations. In this article, the author offers the first attempt on what he calls "a new theoretical-conceptual approach of international criminal law", where international criminal justice through the International Criminal Court, has a major role way.

* Profesor titular de carrera en la Facultad de Ciencias Políticas y Sociales, y profesor de asignatura en la Facultad de Derecho de la UNAM, donde imparte la materias de derecho internacional público. 
SUMARIO: I. Introducción. Enunciado de los principales delitos y crímenes. II. Justicia penal internacional y derechos humanos: la Corte Penal Internacional. III. Una expresión actual de la justicia penal internacional: la Corte Penal Internacional.

IV. Conclusiones. V. Bibliografía.

\section{INTRODUCCIÓN. \\ ENUNCIADO DE LOS PRINCIPALES DELITOS Y CRÍMENES}

El derecho internacional —manifestado específicamente a través de su rama penal - cobra hoy enorme relevancia porque vivimos en el contexto de una sociedad global de características conflictuales y patológicas, donde imperan la violencia, el caos y el desorden, la inseguridad, el demérito de los valores, las conductas delictuosas, los crímenes y las formas de organización internacional criminal, las infracciones a la ley y la impunidad en todas sus acepciones. En este sentido, y a efectos de preparar la entrada al siguiente apartado — que pretende introducirnos a un adelanto de nuestra propuesta de un nuevo enfoque teórico-conceptual del derecho internacional penal- a continuación presentaré sólo a guisa enunciativa, estas disfunciones patológicas que identifican a las relaciones internacionales contemporáneas y que, por cierto, pueden constatarse objetivamente - tipificadas como delitos y crímenes comunes contra los intereses internacionales - en el contenido de los tratados de extradición, bilaterales y multilaterales, firmados y ratificados por la mayoría de los Estados del mapa mundial.

1. Violaciones al derecho internacional humanitario (crímenes de guerra).

2. Genocidio y crímenes contra la humanidad.

3. Violación de derechos humanos de minorías y grupos étnicos (etnocidio).

4. Segregación racial o apartheid.

5. Esclavitud y crímenes conexos.

6. Tortura.

7. Secuestro o rapto y privación ilegal de la libertad. Toma de rehenes.

8. Desaparición forzada o involuntaria de personas.

9. Ejecuciones sumarias y arbitrarias o extrajudiciales.

10. Crimen de agresión. 


\section{Terrorismo internacional.}

12. Homicidio y lesiones graves intencionales.

13. Delitos relativos al tráfico, posesión, producción, elaboración, importación y exportación de drogas (narcotráfico) y productos químicos peligrosos.

14. Tráfico internacional ilegal (personas, armamento, divisas, obras de arte, joyas y gemas, especies de flora y fauna silvestres, órganos humanos, modelos y diseños, etcétera).

15. Mercenarismo internacional.

16. Delitos contra la seguridad de los medios de transporte incluyendo cualquier acto que ponga en peligro a una persona, en un medio de transporte.

17. Ataques contra las Naciones Unidas y su personal (extensivo a otros organismos).

18. Amenaza y uso de la fuerza contra personas que gozan de protección internacional.

19. Violencia oficial contra ciudadanos extranjeros.

20. Violación y estupro.

21. Abandono de menores $\mathrm{u}$ otros dependientes cuando haya peligro de daño o muerte.

22. Pedología (corrupción de menores, incluyendo actos sexuales ilícitos cometidos con menores de edad).

23. Lenocinio internacional (trata de blancas).

24. Robo; robo con violencia, y demás acepciones.

25. Fraude internacional.

26. Abuso de confianza, peculado; malversación de fondos.

27. Delitos relativos a la falsificación en todas sus formas.

28. Extorsión, exacción ilegal.

29. Recibir o transportar sumas de dinero, valores o cualquier cosa a sabiendas de que fueron obtenidas delictuosamente.

30. Incendio intencional y daño intencional en propiedad ajena.

31. Piratería (en todas sus acepciones).

32. Secuestro o apoderamiento ilícito de trenes, aeronaves, barcos u otros medios de transporte.

33. Delitos en materia de armas prohibidas y control de armas de fuego, municiones, explosivos, aparatos incendiarios o materiales nucleares. 
34. Delitos contra el comercio internacional y en materia de transmisión internacional de fondos y metales preciosos.

35. Delitos previstos en las leyes nacionales e internacionales relativas a la importación, exportación o tránsito internacional de bienes, artículos o mercancías, incluyendo objetos históricos o arqueológicos.

36. Delitos en materia aduanal y contra el derecho fiscal nacional e internacional.

37. Conspiración en todos sus tipos, sedición y sabotaje.

38. Delitos previstos en la legislación nacional e internacional relativa al control de sociedades mercantiles, instituciones bancarias y otras personas morales.

39. Delitos previstos en la normativa nacional e internacional relacionada con el mercado de valores, incluyendo la venta de acciones, bonos y títulos de crédito.

40. Corrupción y tráfico de influencias. Soborno a un oficial extranjero.

41. Delitos previstos en las disposiciones legales nacionales e internacionales relacionadas con la quiebra o suspensión de pagos de una sociedad mercantil.

42. Lavado de dinero, otros delitos de "cuello blanco" y enriquecimiento ilícito.

43. Delitos en materia de monopolios y de competencia desleal.

44. Delitos previstos en las leyes nacionales e internacionales relacionadas con la protección de la propiedad industrial y derechos de autor.

45. Delitos previstos en las leyes relacionadas con el abuso de autoridad.

46. Cohecho y concusión.

47. Asociación delictuosa.

48. Espionaje en todos sus géneros y delitos contra la seguridad nacional del Estado.

49. Falsedad en declaraciones judiciales o en informes dados a una autoridad pública distinta de la judicial. Soborno a otro para que se produzca con falsedad.

50. Delitos relativos a la obstrucción de la justicia incluyendo el encubrimiento y la supresión de pruebas. Denegación de justicia.

51. Delitos contra natura (que atenten contra del medio ambiente y los recursos naturales). 
52. Delitos en el orden de la cibernética, la informática y la computación electrónica (piratería, acciones ilícitas "hacker" y "cracker", etcétera).

53. Manipulación no permitida del genoma humano (clonación ilegal, experimentación ilícita).

54. Acciones relacionadas con la pena de muerte, y la muerte piadosa (eutanasia y eugenesia).

\section{Aproximaciones teóricas para la conceptuación del derecho internacional penal}

\section{Génesis breve y antecedentes del derecho internacional penal}

La idea de ley penal y orden punitivo ha acompañado a la humanidad desde sus orígenes, pues es una reacción innata del zoon politikon el proteger sus bienes y desarrollo y el castigar a quienes violan las reglas y el contrato social establecido. En la época antigua se tiene una primera referencia al derecho internacional penal dentro de la civilización egipcia, según lo muestra un tratado de extradición firmado en el año 1280 a. C. ${ }^{1}$ El derecho romano contenía un amplio esquema de penas y castigos para el delincuente, el criminal y el culpable de atentar — sedición - contra el Imperio. Posteriormente, durante el absolutismo renacentista — según lo confirma el maestro A. Quintano Ripollés- el jurista y politólogo Von Bar acuñó el término "derecho penal internacional", lo cual convalidan otros autores al sostener que en siglo XVI se amplían las comunicaciones y se diversifican las relaciones internacionales donde, al mismo tiempo, se afianzan los conceptos de cooperación y coerción internacional. ${ }^{2}$ Otro grupo de estudiosos expresa que los primeros bosquejos claros del derecho internacional penal surgieron a finales del siglo XIX y principios del XX. Aunque según lo asienta el jurista argentino Guillermo J. Fierro, parece que el pionero en utilizar "académicamente" esta denominación fue Jeremías Bentham en sus Principales, editado en 1820, quien se pronun-

1 Bassiouni, M. Ch., International Extradition and World Public Order, Madrid, Fontamara, 1994, p. 341.

2 Quintano Ripollés, Antonio, Tratado de derecho penal internacional e internacional penal, Madrid, CSIC, Instituto "Francisco de Vitoria", 1957, tomo II, p. 117. Como lo veremos más adelante, este autor es el primero en tratar de esclarecer los términos derecho penal internacional e internacional penal. 
cia a favor de su admisión en los tratados generales del derecho de gentes de la época. ${ }^{3}$

Como lo señala Wolfgang Friedmann, en realidad siempre ha existido un derecho internacional penal, hasta ahora aún bastante modesto $y$ mal definido — con el proceso globalizador y la reestructuración de la ciencia jurídica internacional el panorama se ha modificado sustancialmente-. Una parte de él se componía de delitos, no muy importantes, que el derecho internacional clásico consideraba como tales. Quizá sólo dos fueron reconocidos en forma general. Primero, la piratería, delito que evidentemente fue disminuyendo en importancia al ir menguando las actividades de los filibusteros para dar paso a las actividades, a menudo piráticas, de las armadas y demás fuerzas de ataque bajo el control de los Estados. Segundo, el principio generalmente aceptado de que los miembros de las fuerzas armadas beligerantes podrían ser considerados como responsables por violaciones al derecho internacional de guerra o humanitario, y enjuiciados por las autoridades enemigas.

Pero con mucho, desde mediados del siglo XIX, la parte más importante de esta rama ha consistido básicamente en el ajuste de las diferencias entre las jurisdicciones penales de varios Estados para juzgar a sus propios nacionales o a extranjeros, y en particular los conflictos y choques ocasionados por los principios de nacionalidad al ejercer tal jurisdicción. Una aplicación de este principio tiene todavía lugar cuando se comete un delito en la "tierra de nadie" (res nullius), en altamar, donde puede sostener su jurisdicción el Estado de la matrícula del barco del delincuente o de la víctima, el Estado de la nacionalidad del delincuente, o cualquier Estado en cuyas aguas se halle temporalmente el barco.

Consideremos que históricamente tanto por lo que hace al alcance de los delitos internacionales en sí como por lo que toca al ajuste de las jurisdicciones, los acontecimientos propios y los grandes procesos transformadores del siglo XIX y los más drásticos del siglo XX — como las dos guerras mundiales - fueron obligando paulatinamente a la sociedad de Estados a hacer una reconsideración y reclasificación como paso preliminar a la gradual internacionalización del derecho penal, actitud que continúa hasta nuestros días, con un dinamismo creciente. Así, tenemos que en los últimos años ha habido cierta tendencia a equiparar con la piratería

3 Fierro, Guillermo J., La ley penal y el derecho internacional, Buenos Aires, Ediciones Depalma, 1977, p. 5. 
ciertos delitos como el tráfico de personas, la trata de blancas, el narcotráfico, el mercadeo negro de armas, etcétera, pero la dificultad es que se trata de cuestiones distintas. Caso similar lo tenemos en materia de genocidio y etnocidio, donde todo tiende a equipararse a los conceptos de "crímenes contra la paz", "crímenes de guerra" y "crímenes contra la humanidad", adoptados en la Carta de Nuremberg y por los subsecuentes juicios y procesos contra criminales de guerra alemanes, japoneses, yugoslavos y ruandeses.

Para redondear esta breve semblanza retrospectiva del derecho internacional penal, convendría enlistar algunos de los principales esfuerzos históricos que devinieron proyectos fundamentales, que son antecedente y cimiento para un primer intento de sistematización y ordenamiento de esta importante materia:

- Diferentes obras de Jeremías Bentham que tocan el tema penal internacional, 1820-1825.

- Proyecto de Código Internacional Penal, de 1832, por G. de Gregory.

- Proyecto de Código Penal Universal, de 1890, por Von List.

- Constitución de la Corte Permanente de Arbitraje de La Haya, de 1899 (competencia penal).

- Concreción de un Código Internacional Penal, de 1900, promovido por el Congreso Internacional Penitenciario.

- Máximas para la formación de un Código Internacional Penal, de 1905, por el jurista e internacionalista Rafael Garofalo. ${ }^{4}$

- Convenciones de Ginebra sobre Leyes y Costumbres de Guerra, de 1907.

- Iniciativa para la constitución de un Tribunal Internacional, de 1919, por la Conferencia preliminar de la Paz (finalmente se prefirió para lo criminal un organismo inter-aliado ad hoc, para juzgar a presuntos responsables de la guerra y sus crímenes).

- Proyecto de Estatuto de una Alta Corte de Justicia Internacional Penal, de 1920, por el escritor belga, barón Descamps y el español Altamira (fue rechazado por la Asamblea de la Sociedad de Naciones calificándolo de prematuro).

4 Para encontrar mayores referencias a este proyecto se recomienda ampliamente la lectura del texto del profesor de derecho internacional: Garófalo, Rafael, La criminología, Madrid, La España Moderna, Alianza Universidad, 1980. 
- Proposiciones sobre la defensa social penal universal del Tercer Congreso Internacional de Sociología, de 1924, en Roma, por Quintiliano Saldaña.

- Ley de Bases para un Código Penal Internacional, de 1925, por Quintiliano Saldaña.

- Fundación de la Asociación Internacional de Derecho Penal, en 1926 en París, Francia.

- Varias conferencias internacionales para la unificación del derecho penal (Viena, 1926; Varsovia, 1927; Roma, 1928; Bruselas, 1930; París, 1931; Madrid, 1933; Copenhague, 1935; El Cairo, 1938, y, Bruselas, 1947).

- Convenio para la Prevención y Represión del Terrorismo; y Código Penal Internacional, ambos de 1937, en París, por la CPJI de la SDN.

- Tribunal Militar Internacional de Nüremberg, de 1945, por el Acuerdo de Londres.

- Tribunal Militar Internacional del Extremo Oriente, Tokio, 1946, por los aliados.

- Convención Internacional contra el Genocidio, de 1948, por la Asamblea General de Naciones Unidas.

- Proyecto de Código de Delitos contra la Paz y la Humanidad, de 1951, por la Asamblea General de Naciones Unidas.

- Proyecto de Código de Derecho Penal Internacional, de 1959, por Alberto Levitt.

- Cátedra de derecho penal internacional, en la Universidad de Lieja, de fines de los cincuenta a principios de los sesenta, por el profesor Stephan Glaser. ${ }^{5}$

- Cátedra de derecho penal internacional y justicia criminal internacional, impartidas en el periodo 1957-1962, por el profesor y especialista en derecho internacional Wolfgang Friedmann, en las universidades de Columbia (apoyado por el profesor Henkin) y de Londres (en colaboración con el profesor Kahn-Freund).

5 Este listado inicial fue elaborado con base en la consulta de diferentes textos, entre los que destacan el de Fierro, Guillermo J., op. cit., nota 3, pp. 5-7, y el artículo de Palacios, M. J., "Derecho penal internacional y derecho internacional penal, su diferencia y reformas que se proponen a la Constitución y otras leyes", Biblioteca del INACIPE, pp. 1-13. 


\section{Precisión conceptual y terminológica del derecho internacional penal ${ }^{6}$}

El derecho internacional penal o penal internacional, tomado por ahora como concepto dual o equivalente, es la convergencia de dos ramas del derecho, a saber: el derecho internacional y el derecho penal, situación que al mismo tiempo ha sido la causa de su ambigüedad como género autónomo. Para acercarnos a una precisión del concepto y el término en cuestión, esbozaré ciertos enfoques teóricos que han intentado delimitar el conjunto de normas legales que debieran ser agrupadas bajo el derecho internacional penal, al que también se le ha llamado "derecho de aplicación exterior penal", "derecho penal extranacional", "derecho penal interestatal" y "derecho procesal internacional". ${ }^{7}$

De los representantes de la Escuela rusa de derecho internacional destacan, por un lado, el tratadista G. Martens, quien considera al derecho criminal internacional como "el conjunto de reglas jurídicas que determinan las condiciones en las cuales deben auxiliarse mutuamente los Estados a fin de asegurar el ejercicio del poder penal en la esfera de la comunidad de las naciones". ${ }^{8}$ Por la otra, el célebre profesor Gregory I. Tunkin, sin llegar a una definición concreta, sostiene que son conductas que debe erradicar el orden interestatal penal cooperativo:

La prolongación del colonialismo en todas sus formas y manifestaciones, incluyendo el racismo, el apartheid, la explotación de recursos económicos y humanos por extranjeros y otros grupos, y la conducción de guerras colo-

6 Aunque referida al ámbito interno del Estado y no al ámbito internacional, resulta ilustrativo saber que la expresión derecho penal ha sido definida de diversas maneras. Giuseppe Maggiori (Derecho penal, Bogotá, Themis, 1971, vol. I, p. 4) la determina de dos formas: por un lado, según se haga referencia al ordenamiento normativo, y, por otro, a la ciencia, y explica que "estos dos aspectos del derecho penal, distintos por necesidad de estudios son en sí inseparables. Forman dos procesos que se complementan uno con otro, dos segmentos del círculo que se unen, hasta formar la totalidad de la ciencia como unidad de pensamiento y ser... el derecho penal es el sistema de los conocimientos científicos relativos al derecho de la pena".

Por su parte, el penalista español Eugenio Cuello Calón (Derecho penal. Parte general, Barcelona, Bosch, 1975, vol. I, p. 7) lo divide en subjetivo y objetivo. En el primer caso, lo define como "derecho del Estado a conminar la ejecución de ciertos hechos (delitos) con penas, y, en el caso de su comisión, a imponerlas y ejecutarlas". En otras palabras, es el derecho de castigar (jus puniendi). En sentido objetivo, lo describe como "conjunto de normas jurídicas establecidas por el Estado, que determinan los delitos y las penas". Es decir, es el conjunto de normas que integran un ordenamiento jurídico que establece el Estado en el que se fijan los delitos y las penas con que se deben castigar.

7 Asignaciones de autores como Maurach, Mezger, Saver, Welzel, Jeschech, Lombois, Pella, Quintano Ripollés, Angulo y Sáenz de Pipaon.

8 Martens, G., Tratado de derecho internacional, Barcelona, Fontamara, 1990, tomo III, p. 2. 
niales para sofocar los movimientos de liberación nacional... y otros modos de la moderna política de fuerza basada en el modelo imperialista sobre el sistema internacional, (que) contradicen abiertamente al derecho internacional. ${ }^{9}$

La doctrina penal alemana, cuyos exponentes niegan la existencia del derecho internacional penal, sostiene que el contenido que tradicionalmente se le confiere a éste es de naturaleza nacional, ya que se trata de normas que cada uno de los Estados sanciona unilateralmente a fin de establecer el ámbito espacial de su propio derecho. En esta tesitura, Antonio Quintano Ripollés, jurista español, coincide relativamente con los penalistas alemanes, precisando además que se trata de una temática principalmente procesal, y muy especialmente aquella concerniente a los conflictos jurisdiccionales; sin embargo, le otorga al derecho internacional penal la materia que comprende a todas las infracciones que vulneran a la comunidad de naciones o a un grupo de ellas. En otros términos —no dejando de advertirse cierta contradicción en su postura-, para este autor la sustancia del derecho internacional penal son todos los delitos de tipificación internacional por vía convencional, que lesionen bienes jurídicos que interesen a toda la comunidad internacional. ${ }^{10}$

El jurista italiano Francesco Antolisei, quien ha incursionado en los ámbitos estatal e interestatal penal, por un lado nos ilustra con el argumento de que el fin primordial de esta disciplina es el "impedir la comisión de los delitos; en otras palabras, combatir el lamentable fenómeno de la delincuencia o criminalidad, tanto al interior de los Estados como al exterior de ellos". Y seguidamente aduce que — en abierta contracorriente respecto a los criminalistas alemanes y algunos españoles- el derecho penal a la luz de la realidad social mundial actual está incompleto, por lo que debe necesariamente ampliarse y difundirse al escenario internacional y dejar de ser únicamente reconocido como un derecho local y estatal. Asimismo, Antolisei nos previene de las actitudes reaccionarias de algunos sectores del pensamiento jurídico penal moderno, al afirmar que

9 Tunkin, Gregory I., El derecho y la fuerza en el sistema internacional, México, IIJ-UNAM, 1989, p. 179 (obra traducida del ruso al español por el profesor Manuel Becerra Ramírez).

10 El profesor Quintano Ripollés ha elaborado diferentes conceptos del derecho penal y del penal internacional. En el primer caso, ha coincidido con el penalista mexicano Raúl Carrancá y Trujillo, definiéndolo como "el conjunto de leyes mediante las cuales el Estado define los delitos, determina las penas imponibles a los delincuentes y regula la aplicación concreta de los mismos en el caso de la incriminación”. Derecho penal mexicano. Parte general, México, Porrúa, 1980, p. 17. 
cuando se observó la posibilidad de crear un derecho penal que cruzara las fronteras de un país, empezaron a surgir disputas entre los distintos juristas, escritores e internacionalistas, algunos apoyando la idea y otros desechándola por principio o calificándola de utópica e irrealizable. ${ }^{11}$

Entre otros doctrinarios que admiten la existencia de un derecho internacional penal como tal, están Jeremías Bentham y Von Rohland. El primero acuña el término sin llegar a definirlo, mientras que el segundo lo entiende como "el conjunto de principios de derecho por los cuales el Estado, como miembro de la comunidad internacional, determina el valor territorial de sus normas y leyes penales respecto a las personas y a los bienes jurídicos". ${ }^{12}$

Por su lado, el jurista francés Martitz aduce que derecho penal internacional o internacional penal son términos semejantes, referidos a una sola materia, que puede entenderse como un "sistema de reglas de derecho concernientes a la aplicación al extranjero del derecho penal nacional, o... del derecho penal interno". Mientras que el investigador Meili — citado por Guillermo J. Fierro- lo discierne como "el conjunto de leyes y principios de derecho que resultan del hecho de que actos delictivos caigan o parezcan caer bajo el imperio de leyes penales de Estados políticamente independientes unos de otros".

Enfocando nuestra revisión a los representantes de la que podríamos denominar una escuela jurídica sudamericana, destaca en primer término el penalista uruguayo Carlos Alcorta, quien dice que "El derecho penal internacional tiene por objeto el determinar la norma (jurisdicción o ley) aplicable a la acción delictiva de un objeto, cuando esto afecta el orden jurídico de dos o más Estados". ${ }^{13}$

En esta trayectoria ubicamos también al internacionalista y jurista chileno R. Diena, quien nos proporciona un concepto más elaborado e ilustrativo para los efectos de nuestra investigación. Él consigna que el derecho internacional penal es “...la parte del Derecho Internacional que comprende las normas determinantes de la competencia legislativa y judicial de los estados particulares, para la represión de los delitos y que re-

11 Antolisei, Francisco, Manual de derecho penal. Parte general, Bogotá, Editorial Themis, 1988 , p. 1. En este y otros trabajos posteriores, este autor comienza a incursionar en los razonamientos jurídicos que conducirán poco más tarde a perfilar un concepto más acabado del derecho penal en su dimensión internacional.

12 Fierro, G. J., op. cit., nota 3, p. 5.

13 Citado por Vieira A., Manuel, El delito en el espacio. Derecho penal internacional y derecho internacional penal, Uruguay, Editorial Fundación de Cultura Universitaria, 1969, vol. I, p. 18. 
gula el procedimiento que ha de seguirse en los estados para la buena marcha de la justicia penal". ${ }^{14}$

En el contexto latino y continental europeo hay otros autores que merecen nuestra atención. Es el caso de Donnedieu de Vabres, catedrático de la Universidad de París, quien concibe a esta especialidad como "...la ciencia que determina la competencia de jurisdicciones extranjeras, la aplicación de sus leyes criminales en orden a los lugares y a las personas que a ellas rigen, y la autoridad sobre su territorio de las sentencias represivas extranjeras". 15

El jurista ítalo-argentino Eugenio Jovene expresa que la rama penal internacional "Consistiría en el complejo de normas jurídicas que establecerían penas para aquellos delitos que ofenden al interés internacional, penas que debieran ser aplicadas por parte de un órgano superestatal". ${ }^{16}$

Otros estudiosos, como el tratadista italiano de la Universidad de Roma, Filippo Grispigni, estima más relevante hablar del contenido, que acerca de la denominación del derecho internacional penal, el cual en su opinión radica en el “...conjunto de normas que determinan los límites recíprocos las distintas competencias nacionales en el orden penal y en la obligación de asistencia y auxilio (cooperación y ayuda internacional) en la represión de la delincuencia que mutuamente se deben entre sí los diversos Estados". ${ }^{17}$

No hay que dejar de considerar asimismo que existen publicistas como el profesor portugués Vespasiano V. Pella, quien define el contenido de nuestra materia como "La ramificación del derecho público internacional que determina las infracciones, que establece las sanciones y que fija las condiciones de la responsabilidad penal internacional de los estados e individuos". ${ }^{18}$

Algunos otros pensadores jurídicos de la Europa no continental consideran que el derecho internacional penal es el conjunto de normas que definen los límites recíprocos de la aplicación de la ley penal en el espacio; entonces los preceptos no son ni de derecho penal ni de derecho procesal; aquí se ubican exponentes como Mezger, quien supone que se trata de un "derecho de aplicación del derecho penal, admitiendo la íntima co-

16 Quintano Ripollés, Antonio, op. cit., nota 2, p. 345.

17 Fierro, G. J., op. cit., nota 3, p. 8.

18 Palacios, M. J., op. cit., nota 5, p. 4. 
nexión existente entre ambos". ${ }^{19}$ Por su parte, el inglés Levi estima la relevancia que para la ley penal tiene la extranjería, y junto con Goldschmidt conciben la norma penal, el delito y la sanción en un plano de posible realidad supraestatal, con dispositivos reguladores y la presunción de un organismo jurisdiccional supremo; este concepto nos remite ya a la idea de una sociedad que mezcla relaciones entre Estados y/o instituciones a nivel internacional conformando nuevas vías de conexión donde se entrecruzan jurisdicciones bilaterales con delitos globales.

Al llegar a este punto del presente intento por aproximarnos teóricamente a la conceptuación de la materia que nos ocupa a través de una comparación doctrinal de primera mano es pertinente tratar de discernir si las denominaciones derecho penal internacional, derecho internacional penal y derecho penal interestatal definen una misma realidad jurídica o si bien, por el contrario, admiten una argumentación o ciertas precisiones que pudieran llegar a validar, en su caso, algunos criterios de distinción en la forma, la estructura y el contenido de esta disciplina.

En opinión de los catedráticos franceses Pierre Bouzat y Jean Pinatel, ${ }^{20}$ la que posteriormente también compartirán parcialmente sus compatriotas André Huet y Renée Koering-Joulin, el derecho penal internacional tiene tres ramas: el derecho penal internacional stricto sensu (derecho penal internacional privado), el derecho internacional penal y el derecho penal interestatal. Particularmente los dos primeros autores afirman que la aplicación de las leyes penales en el espacio siempre ha producido problemas graves y delicados, y los segundos se inclinan por una opinión en este sentido, aunque más atemperada y optimista. ${ }^{21}$ Huet y Koering engloban toda esta materia bajo el rubro general de droit pénal international. Por su parte, el publicista norteamericano Roy S. Lee prefiere usar la

19 Ibidem, p. 5.

20 Bouzat, Pierre y Pinatel, Jean, Traité de droit pénal et de criminologie, deuxiéme édition, París, Pierre Libraire Dalloz, 1970, p. 1615.

21 Huet, André y Koering-Joulin, Renée, Droit pénal international, Paris, Thémis, Presses Universitaires de France, 1994, pp. 23-24. En mi particular apreciación esta obra es de las más relevantes a nivel mundial que se han escrito hasta la fecha en el ámbito del derecho internacional penal. Estos autores dividen su obra en dos partes. En la primera, denominada "Derecho internacional penal sustancial: infracciones y sanciones penales" incluyen tres títulos: 1) Infracciones y sanciones penales regidas exclusivamente por el derecho internacional; 2) Infracciones y sanciones penales regidas conjuntamente por el derecho internacional y el derecho nacional, y 3) Infracciones y sanciones penales regidas por el derecho nacional. En la segunda, que llaman "derecho penal internacional procesal: acciones derivadas de la infracción", incorporan dos títulos: 1) La autarquía: las reglas que no implican la ayuda mutua para la represión internacional, y, 2) La ayuda mutua para la represión internacional (aquí dedican alrededor de cien cuartillas al tema de la extradición). 
nominación criminal international law para hacer referencia a lo que en español traduciríamos como "derecho internacional criminal o penal".

A este respecto y compartiendo la opinión de Bouzat y Pinatel, la profesora Lucinda Villarreal Corrales es de la idea de que el derecho penal internacional en sentido estricto se refiere a conflictos que nacen de la infracción al orden interno de un país, donde resultan atendibles: la nacionalidad del autor, del coautor o del cómplice de la infracción, la nacionalidad de una o de todas las víctimas de la infracción; el territorio donde se ha cometido la infracción o donde ha producido sus efectos la infracción. Esta rama del derecho - conforme a estos estudiosos - no debe ser calificada de internacional, en razón de que “...lo único internacional que contiene es la nacionalidad del infractor, y los conflictos que se crean, se resuelven en base a las disposiciones nacionales, que solamente se está en presencia de una rama del Derecho Penal Nacional". Y continúan señalando que en este campo se puede situar a la delincuencia internacional, en virtud de que las comunicaciones actuales facilitan los delitos que los sujetos de un determinado Estado pueden cometer fuera de sus fronteras y permite que los delincuentes encuentren rufugio accesible en países distantes. "Estas organizaciones delictivas realizan actos reprobados por la moral y el orden público internacional (terrorismo, narcotráfico, trata de blancas e infantes, falsificación de moneda, etcétera)". ${ }^{22}$

Por lo que concierne al derecho internacional penal, se afirma que tiene por función resolver las litis y los conflictos contra el orden público internacional, teniendo por principal característica la de que afecta a las relaciones internacionales y se sitúa en el ámbito del derecho internacional público o del derecho internacional general - como lo denominamos los publicistas- Los conflictos surgen de la conducta de los individuos que realizan actos prohibidos por el derecho internacional público y regulados directamente por sus ramas especializadas, una en materia humanitaria y, la otra, en los derechos humanos (de cuño mucho más reciente). Se trata, por ejemplo, de los crímenes de guerra y las violaciones graves y acciones criminales contra los derechos humanos fundamentales. Por último, afirman los autores citados que - lo cual no compartimos por razones que, por tiempo y espacio, no argumentaremos de momento- las re-

22 Villarreal Corrales, Lucinda, La cooperación internacional en materia penal, México, Pac, 1997, pp. 116-118. 
glas para solucionar estos conflictos y controversias están contenidas en lo que ellos denominan "derecho penal internacional" en sentido estricto.

En el derecho penal interestatal, los actos prohibidos serían el resultado de órdenes giradas por los gobiernos, como parte de la política sistemática seguida por un Estado, como por ejemplo la declaración de guerra. En este sentido, la responsabilidad penal que se origina sería la responsabilidad de sus dirigentes o la responsabilidad del Estado mismo.

Nuestra opinión al respecto sería la siguiente: si bien es cierto que en tratándose de los dos primeros niveles jurídico-disciplinarios del derecho internacional general en su dimensión penal, enfrentamos confusiones y ciertas imprecisiones que ya requieren ser rigurosamente analizadas y aclaradas sistemáticamente; en lo que respecta al tercer nivel, el penal interestatal, éste representa a nuestro modo de ver toda una estructura normativa de fundamental importancia en las relaciones internacionales penales contemporáneas, principalmente por cinco razones:

a) El Estado asume hoy día el mayor rango de responsabilidad penal internacional por actos ilícitos y violaciones al orden legal internacional, cometidos habitualmente por sus órganos de gobierno.

b) En buena medida los grandes crímenes del pasado y de la actualidad están claramente identificados como "crímenes y delitos de Estado".

c) El Estado, común y generalmente, ha gozado de impunidad cuando incurre en infracciones, y ha dispuesto para sí en el contenido del derecho internacional, todo un corpus de reglas de excepción a su responsabilidad internacional — de todo género-, que maneja con singular ambivalencia y "destreza", al responder tanto a las reclamaciones que le llegan a interponer otras unidades políticas, como a las demandas y reparaciones que le exige la sociedad internacional como un todo.

d) Las principales instituciones judiciales internacionales competentes para resolver controversias entre los Estados - a saber: la Corte Permanente de Arbitraje de La Haya (1899) y la Corte Internacional de Justicia (1945) — no tienen jurisdicción obligatoria para las partes en litigio; esto es, son facultativas, amén de que son de carácter general, es decir, no se especializan en materia penal, lo que ha disminuido históricamente su eficiencia y eficacia, particular- 
mente cuando abordan delitos, crímenes y asuntos de naturaleza delicuencial y criminal.

e) Se parte erróneamente del supuesto de que los infractores más importantes son los individuos, por encima incluso de los propios Estados, motivados esencialmente por razones y causas propias, lo cual se refleja, por ejemplo, en la competencia exclusiva y única que la Corte Penal Internacional establecida en Roma en 1998 tiene sobre los individuos particulares y no sobre los Estados, lo cual igualmente ocurre con los tribunales ad hoc instaurados, antes en Nüremberg y Tokio, y recientemente para Yugoslavia y Ruanda, dirigidos a juzgar crímenes cometidos por sujetos particulares en $\mathrm{Yu}$ goslavia y Ruanda.

Sin embargo, bien vale la pena hacer hincapié -y como una relevante excepción a la regla - en la jurisdicción que sobre los delitos cometidos por los Estados, no contra otros Estados sino contra individuos nacionales y extranjeros, tienen instancias judiciales internacionales regionales como las cortes de derechos humanos establecidas a niveles interamericano e intereuropeo.

Continuando nuestro recorrido analítico, cabría hacer un alto breve y meditar sobre el hecho de que difícilmente podríamos arribar — al menos en las actuales circunstancias y con las limitaciones que impone un mundo que no termina de ordenarse - a un concepto único y universalmente válido, que englobe consensualmente lo que debemos entender por derecho internacional penal, tanto por lo que respecta a su naturaleza, contenido y fundamento, como por lo que concierne a las fuentes, la organización interna y la estructura-función de aplicación, más aún si consideramos que este nuevo campo disciplinario se encuentra en plena formación y evolución, y que - ciertamente - se trata de cuestiones nada sencillas que nunca han quedado del todo aclaradas aun en el propio terreno epistemológico del derecho internacional general, con varias centurias de existencia. Esta realidad objetiva nos explicaría la razón de la existencia de tantas doctrinas y escuelas de pensamiento, y tan múltiples y variados enfoques teóricos, perspectivas analíticas y paradigmas explicativos.

Tal es el caso de las distinciones que en la materia que nos ocupa ya hemos mencionado y las que hacen otros juristas, como ese enorme pensador del derecho y de las relaciones internacionales que fue Hans Kelsen. Para él, la ciencia del derecho internacional será verdadera, en tanto los ac- 
tos coercitivos de los Estados y la intervención de un Estado por la fuerza en la esfera de intereses de otros se permita como reacción de la comunidad jurídica internacional contra un acto ilícito; esto es, que el empleo de la fuerza está prohibido para cualquier otra finalidad. En el ámbito de las relaciones internacionales los Estados cometen actos ilícitos y conductas ilegales contrarias al derecho internacional, llegando incluso a incurrir en responsabilidad del orden penal internacional, y ante estas conductas, existe la sanción, como una obligación de reparar la violación, el daño moral o material infringido. Agrega Kelsen que la reparación de tal daño debe propender al restablecimiento de la situación original, como si aquél no se hubiera ocasionado (atengámonos a que esto no ha sido ni es siempre posible), y que ello supone la actuación de una autoridad supranacional aún inexistente, que determine la ocurrencia de un acto ilícito, con facultades para imponer la sanción. ${ }^{23}$

Por cuanto concierne a los exponentes del pensamiento mexicano en este campo específico del conocimiento jurídico, es elocuente el hecho de que los principales publicistas y los autores más reconocidos de la literatura penal nacional prácticamente no abordan el tema del derecho internacional penal en ninguno de sus textos, programas, cátedras o investigaciones. Sin embargo, son de mencionarse las aportaciones —aún muy limitadas - de algunos estudiosos y académicos de la Universidad Nacional Autónoma de México (Instituto de Investigaciones Jurídicas, Seminario de Derecho Penal de la Facultad de Derecho, Seminario de Derecho Internacional y la Cátedra UNESCO de Derechos Humanos de la Facul-

23 En nuestra opinión, la sanción no es requisito sine qua non para el cumplimiento del derecho internacional, aunque en ciertas situaciones sí resulta ser necesaria. En un sentido de actuación, los Estados lo hacen convencidos de que la observancia de la norma de gentes y de los tratados internacionales se logra a través del principio ex consensu advenit vinculum, esto es, "el consentimiento es la base de la obligación jurídica". En el otro, es ostensible que sí existe coercibilidad en las disposiciones internacionales, pues la historia muestra que los Estados y la comunidad internacional siempre han sancionado a las naciones que cometen actos violatorios de los principios y disposiciones internacionalmente aceptados y establecidos — aunque habría que evaluar históricamente qué tanto es cierto que se ha actuado con imparcialidad al materializar la sanción, no haciendo distingo entre países fuertes y países débiles, o entre vencedores y vencidos-. El hecho es que las sanciones se han expresado a través de las declaraciones de guerra, represalias, bloqueos, embargos, la conquista (ahora proscrita por la ONU), la cesión (onerosa, por contrato, testamento, permuta, en caso de rectificación de fronteras), el derelitio (evacuación o abandono del territorio o de derechos), las invasiones, etcétera. Las sanciones hoy se incluyen en los textos y programas modernos de derecho internacional público, y son las siguientes: la retorsión (en sentido actual), las represalias pacíficas (en sentido clásico), la legítima defensa, la autoprotección, la compensación económica, la seguridad colectiva (mantenimiento de la paz y seguridad internacionales), la suspensión de derechos y la disminución de prerrogativas (organismos de integración). 
tad de Ciencias Políticas y Sociales), de la Universidad Iberoamericana (campus Santa Fe), de la Universidad Autónoma Metropolitana (campus Azcapotzalco), de la Escuela Libre de Derecho, y del Instituto Nacional de Ciencias Penales (INACIPE). Igualmente, reconocemos los esfuerzos de instituciones oficiales como la Comisión Nacional de Derechos Humanos. Por último, hemos detectado contribuciones atendibles de ciertas organizaciones no gubernamentales, como la Comisión Mexicana de Defensa y Promoción de los Derechos Humanos, A. C., así como muy pocos investigadores independientes. En suma, el campo del derecho internacional penal en México se encuentra aún inexplorado y con un amplio potencial por delante, principalmente si consideramos tanto la creciente importancia que en nuestro país se está dando al estudio, promoción y defensa del derecho internacional de los derechos humanos, como la reciente firma por el Ejecutivo Federal -7 de septiembre de 2000- del Estatuto de Roma que establece la Corte Penal Internacional.

Retomando este breve recorrido conceptual y para concluirlo con definiciones que nos brindan especialistas mexicanos seleccionados, aparece primeramente Miguel Ángel Cortés Ibarra, quien señala que en la actualidad no puede hablarse de la existencia plena de un derecho penal internacional, ya que ello implicaría trascender la fase en que éste se encuentra de la evolución progresiva, la cual es definida por la Comisión de Derecho Internacional de la ONU “como la preparación de convenciones sobre asuntos que no han sido regulados todavía por el Derecho Internacional o en relación a los cuales el Derecho, en la práctica entre los Estados, no ha evolucionado lo suficiente". Y, según este autor, “...hasta la fecha no existen esos acuerdos; sin embargo, en diversos congresos verificados, se ha planteado la necesidad de elaborar un Derecho Internacional Penal con objeto de protegerse contra actos que afectan o pongan en peligro la seguridad de las naciones".

El profesor Cortés aduce finalmente que el paso a seguir sería la codificación, a cargo de la propia Comisión de Derecho Internacional, y para lo cual sería previamente recomendable la constitución de un tribunal penal internacional y la convocatoria a una convención multilateral de amplia participación para “...establecer la creación de un Código Penal Internacional”. ${ }^{24} \mathrm{Al}$ respecto, nuestra visión es en el sentido de que el de-

24 Cortés Ibarra, Miguel Ángel, Derecho penal. Parte general, México, Cárdenas Editor y Distribuidor, 1987, pp. 9-10. Cabe acotar que la Comisión de Derecho Internacional de la ONU define a la 
recho internacional penal sí es una realidad, pues si bien algunos de sus temas están en fase de evolución progresiva, otros ya se encuentran codificados desde hace varios años, como es el caso de la piratería, el genocidio, y los delitos de guerra.

Por lo que respecta al maestro Modesto Seara Vázquez, reconocido autor y catedrático de derecho internacional en la UNAM y actualmente rector de la Universidad de la Mixteca y de la Universidad del Mar, su pensamiento es en la tónica de que los tiempos presentes son los tiempos de un derecho internacional penal más sistemático, consistente, democrático y con mayores perfiles de efectividad en su aplicación y observancia. Y ello lo inscribe en el marco de la reforma general del sistema de las Naciones Unidas, a la cual incluso ya dedicó una obra completa. ${ }^{25}$

En una entrevista más o menos reciente declaró sobre la norma penal internacional y el terrorismo lo siguiente:

...las injusticias y frustraciones legítimas eran el fondo del terrorismo, pero también detrás se escondían muchas reivindicaciones aparentemente legítimas como propósitos espurios, de venganza o de beneficio personal... las convenciones internacionales que ya existen -integrantes del derecho internacional penal- deberían ser sistematizadas en una convención general, que las actualice y complete. Además de que sería importante proclamar al terrorismo como un delito jure gentium, y habría que establecer con carácter permanente una Corte Internacional Penal, para la persecución de todos los delitos contra el derecho de gentes, del genocidio al terrorismo. ${ }^{26}$

También es del criterio de que el establecimiento de un sistema judicial internacional implicaría "el reafianzamiento de la Corte Internacional de Justicia, la ampliación y representación equitativa de veinte jueces en vez de quince, la creación de cuatro cortes regionales con 5 jueces cada una y la instauración de una necesarísima Corte o Tribunal internacional de justicia penal (con sus respectivos estatutos)" ${ }^{27}$

codificación como "La formulación y sistematización precisa de normas de derecho internacional en aquellas materias en que ha existido práctica amplia, precedentes y doctrina".

25 Son numerosas las obras del estimado profesor hispano-mexicano a quien varios académicos le debemos un reconocimiento especial por su impulso al estudio del derecho internacional y de las relaciones internacionales. Su texto clásico Derecho internacional público, México, Porrúa, es de sobra conocido. En este caso quiero referirme a su libro: Una nueva Carta de Naciones Unidas, México, Universidad de la Mixteca, 1993.

26 Batta, Víctor, "Injusticia y frustraciones legítimas. Terrorismo, preocupación mundial”, El Financiero, México, 11 de marzo de 1996, p. 66.

27 Velázquez Elizarrarás, Juan Carlos, artículo citado, p. 34. 
Otro destacado académico y prolífico autor mexicano que ha incursionado en el mundo de la justicia penal internacional es el jurista Alonso Gómez-Robledo Verduzco. Ya desde 1986, cuando aparece su libro Temas selectos de derecho internacional, incorpora temas en este contexto de nuestro interés, como los siguientes: los tratados de extradición y su supuesta ineficacia; aspectos de la reparación en derecho internacional; el problema del previo agotamiento de los recursos internos, en derecho internacional; jurisprudencia internacional por daños transfronterizos; el estado actual de la jurisdicción internacional y el futuro de la misma; el derecho de asilo en el sistema jurídico internacional; y, ¿Es el terrorismo un delito político?, entre otros. ${ }^{28}$

En idéntica tesitura se ubica su obra aparecida en 1996, Extradición en derecho internacional. Aspectos y tendencias relevantes, donde el colega, luego de obsequiarnos un pensamiento magistral de Raymond Aron, nos introduce en sus consideraciones generales, a algunos conceptos en torno a la materia que nos ocupa. Por ejemplo, nos dice que es de observancia cuasiuniversal el hecho de que el Estado solicitante de la extradición debe contemplar el acto en cuestión como delito tipificado en su orden nacional en forma similar, en cuanto a infracción y pena a la legislación del Estado requerido; principio éste de la doble incriminación. Inversamente, el Estado requerido puede rehusar la extradición, si el acto por el cual ha sido solicitada ha violado sus propias leyes. Éste sería el caso - continúa- cuando fuere constitutivo de dos delitos distintos, o de un delito internacional, o bien el caso de que exista un elemento de un "delito complejo", en donde uno de sus elementos se vincula al Estado requirente.

"Pero en estos dos últimos casos se admite, generalmente, que el Estado requerido deberá real y efectivamente perseguir y sancionar al delincuente. Esta alternativa puede advertirse en el texto de múltiples convenciones internacionales". ${ }^{29}$

Asimismo, es del criterio de que el sistema internacional evoluciona con lentitud y dificultad, aunque de manera irreversible hacia "una ampliación de la esfera de un derecho penal en las relaciones internacionales", y que “...aun y cuando todas aquellas conductas que son calificadas

28 Gómez-Robledo, Verduzco, Alonso, Temas selectos de derecho internacional, México, IIJUNAM, 1999.

29 Gómez-Robledo, Verduzco, Alonso, Extradición en derecho internacional. Aspectos y tendencias relevantes, México, IIJ-UNAM, 1996, p. 12. 
como "crímenes internacionales", , son violaciones a cierto tipo de obligaciones erga omnes; sin embargo, hay que tener muy claro que no toda violación a una obligación con efectos erga omnes constituye necesariamente un "crimen internacional", como tampoco constituye forzosamente una infracción a una norma de ius cogens. En esta lógica, podríamos entonces aducir que "Normas de ius cogens, 'crímenes internacionales' y obligaciones erga omnes, son obviamente categorías jurídicas relacionadas entre sí, pero no por ello equivalentes, en un sentido u otro, como ha quedado demostrado cuidadosamente en los diversos trabajos, discusiones e informes presentados por la Comisión de Derecho Internacional". Y concluye argumentando que es al interior de este mismo razonamiento, "...donde debe considerarse el establecimiento de un tribunal internacional ad hoc, para crímenes cometidos en el territorio de la ex Yugoslavia. En otras palabras: debemos considerarlo como un primer paso hacia una jurisdicción penal internacional con competencia universal". ${ }^{30}$

Corresponde ahora resaltar de manera sintética el breve espacio que en su amplísima obra escrita ha dedicado al derecho internacional penal el muy reconocido jurista e internacionalista Sergio García Ramínez. Evocar su nombre nos remonta de inmediato a aquel primer acercamiento que tuvimos en 1976 con su libro Los derechos humanos y el derecho penal (él era entonces subsecretario de Educación Pública y quien suscribe se desempeñaba como subdirector en el mismo sector), que constituye, en nuestra apreciación, el primer intento serio en su género por concatenar dos ramas fundamentales del derecho: una, el derecho penal, muy reposada y de amplio antecedente, y la otra, los derechos humanos, en un estado de desconocimiento casi total y por consiguiente fuera del discurso académico, oficial y social de la época. Aunque el texto no hace mención específica a un derecho internacional penal, contiene dos aspectos que lo perfilan claramente como precursor en el estudio de esta disciplina: a) ubica internacionalmente a los derechos humanos y revisa los derechos

30 Ibidem, pp. 12-13. Para el autor, lo relevante de estos tribunales -incluidos hoy día el de Ruanda y el Penal Internacional de Roma, 1998 - sería el vínculo que se ha querido establecer entre represión de crímenes particularmente abominables, y el mantenimiento de un orden internacional, con estándares mínimos de equidad y seguridad que hagan contrapeso al ejercicio arbitrario del poder. Alonso está convencido de la necesidad de desterrar ideas que considera falaces, como la de "fraternidad universal" o las de un "progreso de la civilización hacia formas ideales de la humanidad", pues en su óptica - a la que no le falta razón histórica- estos conceptos tienen un papel anestésico bien asignado, que no han hecho otra cosa que "mitificar negativamente la realidad de las relaciones internacionales". 
de materia penal contenidos en los instrumentos internacionales vigentes, y $b$ ) escruta en temas como la territorialidad de la ley penal, el asilo y la extradición para encaminar una visión general acerca del límite penal de los derechos humanos en el ámbito internacional. ${ }^{31}$

Ya en tiempos actuales (1998), Sergio García Ramírez presenta la contribución intitulada Derecho penal, donde con cierto titubeo y sin el ánimo de entrar en debate —como él mismo lo advierte- expresa algunas ideas personales sobre lo que él denomina las normas internacionales penales.

Comienza asegurando — sin explicarlo — que hay un debate sobre el concepto de derecho penal internacional. A su juicio, las normas del ius gentium contribuyen a integrar el orden punitivo, cuando han sido recibidas por el derecho interno (suscripción, ratificación, aprobación por el Senado, promulgación por el Ejecutivo, publicación en el periódico oficial), al que aportan tipos y otros puntos relevantes. Aduce que existen numerosos tratados internacionales que interesan a la materia penal. Algunos refuerzan los derechos públicos subjetivos, situación que no ocurre con las declaraciones - aunque él reconoce que hay opiniones en otro sentido-, como es el caso de la Declaración Universal de los Derechos y Deberes del Hombre, y la Declaración Americana de los Derechos y Deberes del Hombre, ambas de 1948. Señala que algunos juristas asignan a éstas valor político y moral, pero no la fuerza vinculante característica del imperativo jurídico. ${ }^{32}$

Empero, se ha abierto paso una corriente — de la que somos simpatizantes- que sostiene que esas declaraciones son normativas, no sólo programáticas, y obligan a los Estados. Coincidimos con el autor en el hecho de que no cabe duda sobre la eficacia de los tratados que derivan de las declaraciones, ya asumidas en el derecho nacional mexicano, como el Pacto Internacional sobre Derechos Civiles y Políticos, de 1966, y la Convención Americana sobre Derechos Humanos, de 1969. Asimismo, percibimos que, en otros casos ya más relacionados con la materia penal, los convenios internacionales fijan obligaciones para los Estados, que influyen sobre la formulación de tipos, como la Convención Única sobre Estupefacientes, de 1961, y el Convenio sobre Sustancias Psicotrópicas, de 1971; mientras otros instrumentos, “de trascendencia más procesal

31 García Ramírez, Sergio, Los derechos humanos y el derecho penal, México, SepSetentasSEP, 1976, 205 pp.

32 García Ramírez, Sergio, Derecho penal, México, McGraw-Hill-IIJ, 1998, pp. 51-53. 
que penal", contienen prevenciones que limitan, por inmunidad, el despliegue de la jurisdicción represiva (Convenciones de Viena sobre Relaciones Diplomáticas y Consulares, de 1961 y 1963, respectivamente).

En otros ámbitos correlacionados, el autor sostiene que los tratados internacionales en materia penal significan un sistema de colaboración entre Estados, concentrándose algunos en ese propósito para la investigación de delitos, o para el enjuiciamiento y la ejecución de condenas. En este sentido, le resultan interesantes los tratados de extradición, como acto típico de auxilio jurisdiccional, al igual que lo relativo al asilo, territorial y diplomático, institución de sentido contrario “...a la extradición: no-colaboración, porque se brinda refugio al perseguido por la autoridad de otro país". 33

En síntesis, compartimos con él la tesis de que la creciente intensidad de la relación internacional conduce al establecimiento de nuevos tratados, convenios o acuerdos entre gobiernos, que poseen relevancia para la materia penal o procesal penal en sus dimensiones nacional e internacional.

Para finalizar el presente apartado, advertimos que se procedió a revisar la obra escrita de otros autores mexicanos en materia de derecho penal —ediciones más recientes - con la idea de encontrar alguna mención al concepto o cierto tipo de tratamiento a la estructura o contenido del derecho internacional penal; pero no se hallaron referencias al respecto. ${ }^{34}$

33 Ibidem, p. 52. El autor señala que sobre asistencia bilateral en procedimientos penales se debe citar el tratado entre México y España, que también abarca la extradición; y el convenio para asistencia recíproca en procedimientos penales, entre México y Estados Unidos, de 1987. En cuanto a ejecución, señala que se ha afianzado el régimen de ejecución de extraterritorial de sentencias condenatorias (o de "repatriación de reos"), fundado en el último párrafo del artículo 18 constitucional, y contenido en los tratados con Estados Unidos, Canadá, Panamá, Bolivia, Belice, España y otros países.

34 Entre los autores consultados están los siguientes: 1) Eduardo López Betancourt, Introducción al derecho penal, 2) José A. González Quintanilla, Derecho penal mexicano, 3) Eduardo Pallares, Prontuario de procedimientos penales; 4) Jorge Ojeda Velázquez, Derecho de ejecución de penas; 5) Mariano Jiménez Huerta, Derecho penal mexicano; 6) Francisco Pavón Vasconcelos, Manual de derecho penal mexicano; 7) Ibidem, Lecciones de derecho penal; 8) Fernando Castellanos, Lineamientos elementales de derecho penal; 9) Juan M. Ramírez Delgado, Penología; 10) Raúl Plascencia Villanueva, Teoría del delito; 11) Rafael Márquez, Derecho penal; 12) Irma Amuchátegui, Derecho penal. 


\section{JUSTICIA PENAL INTERNACIONAL Y DERECHOS HUMANOS: LA CORTE PENAL INTERNACIONAL}

\section{Apreciación filosófico-jurídica y definición inicial de la justicia penal internacional}

Como lo hemos percibido a lo largo del presente artículo, las relaciones internacionales y el derecho internacional se encuentran cada día más profundamente enlazados con el quehacer cotidiano de las sociedades de todos los países del orbe y con la vida en común de la sociedad internacional. Y la actual transnacionalización de múltiples actividades políticas, económicas, sociales y culturales trae aparejada una diseminación multidireccional de las actividades delictivas y las conductas criminógenas que demandan una especial colaboración entre los Estados y por medio de las organizaciones internacionales para prevenir y reprimir, en su caso, las acciones de este género que desde el interior de los territorios estatales tienden a traspasar las fronteras y causar perjuicio o daño a Estados tanto vecinos como de distinta ubicación geográfica, así como para disponer de los medios e instrumentos más adecuados para enfrentar la delincuencia que provenga de otros ámbitos espaciales y que provoque efectos dañosos o transite por el territorio nacional.

Como lo indica la acuciosa investigadora Emma Mendoza Bremauntz, ${ }^{35}$ es de sobra conocido el hecho de que la Organización de las Naciones Unidas ha impulsado desde hace varias décadas el estudio y difusión del denominado derecho internacional penal, que se relaciona con el complejo mundo de la represión del delito y que aún dista de haber alcanzado los niveles de aplicación que se requieren para dar mayor eficiencia y eficacia a las medidas acordadas en las reuniones internacionales, las más importantes de ellas precisamente convocadas por la ONU, organización que resulta ser - conforme fue ratificado en la pasada Cumbre del Milenio, de septiembre de 20 - la instancia supranacional más adecuada para coordinar la cooperación multilateral y estructurar un sistema de justicia penal internacional, requisito sine qua non para enfrentar con éxito el delito internacional y transnacional.

Hoy en día resulta difícil hablar de justicia penal internacional sin hacer referencia obligada a la cooperación penal internacional, y viceversa.

35 Mendoza Bremauntz, Emma, "El delito en la óptica internacional actual”, Indicador Jurídico, México, Anfictionía Unión Universitaria, vol. 1, núm. 4, mayo de 1998, p. 136. 
Los hechos evidencian la importancia que tienen la justicia y la cooperación penal para la prevención y represión de delitos y sus consecuencias en los planos nacional e internacional, en virtud de que - amén de otras razones- el contexto de la delincuencia nacional o interna de los Estados constituye un caldo de cultivo para el desarrollo de la delincuencia internacional, y más aún cuando la criminalidad interna logra la formación de redes eficientes, constituye un importante soporte para las actividades delictivas internacionales organizadas. En las relaciones internacionales contemporáneas es de vital consideración la creciente tecnificación y modernización de las organizaciones delictivas y del crimen organizado, que pone en tela de juicio la calidad de respuesta de las entidades responsables de la ejecución de la ley en la mayoría de los países y en la sociedad de Estados, lo cual refuerza la urgente necesidad de estructurar un nuevo esquema de justicia y cooperación penal internacional, que contrarreste, en la práctica y no en el discurso político o en el infructuoso asambleísmo, un problema que más que internacionalizarse, se ubica ya en los rangos de un verdadero protagonismo global.

En este punto, recordemos que en el Octavo Congreso de las Naciones Unidas sobre Prevención del Delito y Tratamiento del Delincuente se plantearon algunas cuestiones respecto a la cooperación y la justicia internacionales en este tópico, con base en una serie de consultas oficiosas. Ahí se dijo, por ejemplo, que el respeto a la normativa internacional penal $\mathrm{y}$ al principio de legalidad en las relaciones internacionales debe estar presente en toda medida de lucha contra la delincuencia internacional; y que, para ello, "se debe estimular el estudio del Derecho Penal Internacional y hacerse permanente cotejo de la legislación interna y los términos de los acuerdos internacionales". ${ }^{36}$ También se expresó la necesidad de combatir la delincuencia internacional en forma legalmente planificada y con el apoyo de personal especialmente capacitado, buscando adecuar la legalización y la justicia, no sólo penal sino civil y administrativa vigente, a las nuevas formas delictivas. ${ }^{37}$

36 Ibidem, p. 137.

37 Ahí se hace una llamada especial para la lucha contra la contaminación grave y ascendente, la explotación irracional y la consecuente destrucción del medio ambiente —los denominados delitos contra natura - , utilizándose no sólo el derecho civil y administrativo, sino también el penal, nacional e internacional, para detener esta alarmante devastación, proponiéndose el estudio de los que serían principios rectores para la prevención de los delitos contra el entorno ambiental. Asimismo, y en razón del abuso de las tecnologías avanzadas y de los conocimientos técnicos especializados para la realización de actividades delictivas, principalmente en el comercio internacional, como fraudes por 
Tratándose de aspectos directos y concretos de la justicia penal internacional, destacan algunos argumentos sobre los que nos invita a reflexionar - con los que coincidimos plenamente, salvo algunas acotaciones que haremos en su oportunidad - el penalista mexicano Sergio García Ramírez. En un primer nivel, se trata de esclarecer lo que hoy se conoce como alcance de la justicia penal. Cabe entonces hacer una breve cogitación sobre la trascendencia territorial, siempre en auge, de la justicia penal. Se trata de una cuestión delicada - a la que no pocos autores le "dan la vuelta" - , que tiene un escenario y unas oportunidades mucho mayores que el tema penal, y en el que "reviste algunas de sus aplicaciones más polémicas y dramáticas. Se trata de establecer los linderos de la soberanía. Por lo tanto, no estamos ante un asunto menor". ${ }^{38}$ A partir de la segunda posguerra se ha llegado al consenso internacional de que la movilidad de la delincuencia debe compensarse y combatirse con la movilidad de la justicia penal; la cual debe ser ubicua - como lo sostenía Beccaria - para que "no haya lugar donde encuentre refugio el criminal". En términos de las actuales relaciones internacionales, ese antiguo rechazo a la impunidad significa "...una acción persecutoria tan amplia como sea practicable y una colaboración persecutoria tan resuelta como sea posible". Y con este razonamiento se logra derribar un gran obstáculo tradicional a la justicia penal: la prohibición de entrega de nacionales; aunque aún hay disposiciones en sentido contrario, como es el caso de la Constitución alemana, que preceptúa: "ningún alemán podrá ser entregado al extranjero..." (artículo 16, 2). ${ }^{39}$

Empero, la realidad mundial y global tiende a imponerse cada vez con más fuerza; así tenemos que los Estados ya no se reducen a los principios de territorialidad y personalidad en la aplicación de la ley penal, esto es, hoy prolifera un complemento natural: la ley nacional se aplica a cualesquier individuos por la comisión de ciertos delitos abominables, independientemente del lugar en que fueron realizados (de esta regla hay aplicaciones bien conocidas, como el caso de Adolf Eichmann). Y el al-

computadora, abuso de los servicios bancarios, manipulación de disposiciones fiscales aduanales, se hace inaplazable la capacitación adecuada de los funcionarios encargados de la represión de estos delitos, requiriéndose además la cooperación de otros organismos competentes en el nivel interno y aptos en el nivel internacional.

38 García Ramírez, Sergio, "Panorama de la justicia penal", La ciencia del derecho durante el siglo XX, México, IIJ-UNAM, 1998, pp. 711-758.

39 Ibidem, p. 753. 
cance de la justicia penal internacional va más allá, pues “...este ímpetu persecutorio llega al extremo de cuestionar o negar el principio ne bis in idem, como lo autoriza el Convenio Europeo sobre Transmisión de Procedimientos en Materia Penal" o el propio Estatuto de Roma de 1998, que establece una Corte Penal Internacional - al cual dedicaremos parte importante del presente apartado.

En un segundo nivel, el de la codificación y jurisdicción, se afirma que una consecuencia regular de este género de preocupaciones, vinculadas además a los hechos de la segunda conflagración mundial, es la aparición de una justicia penal internacional en su triple expresión:

a) como catálogo de delitos y crímenes;

b) como sistema de enjuiciamiento, $y$

c) como régimen de ejecución.

De esta manera, la sociedad internacional de Estados, congregados por una cultura jurídica común — que se cifra en el derecho convencional, en la costumbre internacional o en los principios generales del derechose organiza y hace frente al flagelo de la delincuencia y el crimen.

Aquí surgen diversas cuestiones, que destaca nuestro autor. Una de ellas es la incorporación al sistema jurídico estatal o interno de "tipos penales anticipados y acordados en sendos convenios internacionales, que abundan, y que es una especie de vértice para el encuentro del ius gentium con el ius civile". Otra es la responsabilidad internacional del Estado por hechos de sus servidores - o de sujetos que actúan de facto, por la cuenta o con la complacencia del Estado_-, que es una responsabilidad colectiva. Sin pasar por alto una más que es la responsabilidad internacional de los individuos por los crímenes que cometen, sea bajo el imperio del derecho local, sea bajo los términos del derecho internacional, que constituye una responsabilidad individual típicamente penal. En este punto coincidimos con la opinión de García Ramírez en el sentido de que nos hallamos en la zona moderna y progresiva del derecho internacional: ahí donde el individuo comienza a ser sujeto directo y genérico del derecho de gentes, a título de sí mismo, no de súbdito o agente del Estado, como fue tradicional y lo recogió la doctrina clásica, hoy ya superada. En esta lógica, "Un auténtico derecho internacional penal debería... contener auténticos tipos penales que obliguen directamente al individuo, desplazar 
al derecho doméstico y superar la objeción de soberanía en la persecución de los delitos". ${ }^{40}$

También se asigna con razón que principios de Nüremberg y Tokio pusieron en marcha la elaboración de la justicia penal sustantiva; también fijaron una referencia jurisdiccional para la constitución de un tribunal penal internacional — como el que hoy es una naciente realidad — a partir de un supuesto básico: la creación de un poder punitivo supraestatal, que no contradice la tendencia de las relaciones internacionales. Esto conduce, como parte inseparable del paradigma de la justicia penal internacional, a la formación de tribunales internacionales con el triple sustento que les adjudica Hans Kelsen: $a$ ) integrados por jueces independientes; $b$ ) dotados de competencia para resolver controversias internacionales bajo el derecho internacional, general y penal, y $c$ ) investidos con la capacidad de resolver con la mayoría de sus integrantes. "En esta arena movediza, el final del siglo nos encuentra con algunas novedades: los tribunales dispuestos por el Consejo de Seguridad de las Naciones Unidas para enfrentar los crímenes de autoridades en la antigua Yugoslavia y en Ruanda". Cabe aclarar que el estudio detallado de estas dos instancias jurisdiccionales es fundamental para comprender lato sensu el sustento actual y los retos inmediatos de la justicia penal internacional y de la Corte Penal Internacional, y que, de momento, queda fuera de nuestro alcance.

En un orden paralelo de ideas, cabe afirmar que la justicia penal internacional es un corpus y un sistema inconcebible e irrealizable si se le pretendiera soslayar o apartar - como algunos pudieran llegar a suponer- de su vinculación histórica con el derecho internacional humanitario y con el derecho internacional de los derechos humanos. En esta tesitura, juristas como el que ahora nos ocupa se preguntan acerca de la eficacia incriminadora de las condenas emitidas por tribunales internacionales y regionales de derechos humanos. Evidentemente $-\mathrm{y}$ se afirma bien - se trata de cuerpos colegiados no punitivos, de cortes no penales;

40 Ibidem, p. 754. El autor es de la idea de que un concepto moderno de justicia penal internacional parte de una concepción también novedosa y visionaria del derecho internacional, al considerar éste, por ejemplo, la subjetividad plena y actuante ante él del individuo, pues sólo así se podrá suponer que la justicia penal del porvenir asumirá los cambios que le imponga la necesidad de tutelar con eficacia los intereses sociales y la paz pública internacional. La justicia penal internacional tendrá el contenido que determinen las variaciones, cada vez más expeditas, en las ideas morales y las modalidades que reclame la nueva relación entre el hombre y el Estado. Asimismo, en este ámbito habrá de superarse "...la pugna entre derechos humanos y orden público... no siempre habrá movimientos dramáticos; es posible que venga una erosión lenta, que abandone las conquistas del derecho penal democrático", p. 756. 
sin embargo, tampoco pueden ser irrelevantes sus fallos y sentencias para la justicia penal interna, cuando indician — señalan directa y probadamente- a los autores de las violaciones que tienen una doble calificación: hechos ilícitos en el derecho internacional y delitos en el doméstico. No se pase por alto el hecho real de que la responsabilidad del Estado proviene precisamente de la conducta, activa u omisiva, de sus agentes, individuos en concreto, y, de no haber ésta no habría aquélla; además de que las reparaciones — que son consecuencias jurídicas de la responsabilidad internacional - abarcan la persecución y sanción penal de quienes son personalmente responsables de la violación, ésta por lo general en contra de los derechos humanos y del derecho internacional humanitario.

Obviamente, la legítima actividad persecutoria de los Estados al aplicar su propia ley a hechos realizados fuera de su territorio, o de la comunidad internacional al operar bajo el derecho internacional penal no puede ni debiera ser confundida en situación alguna “...con la injerencia desbordante que fiscaliza y castiga la conducta de otro Estado por hechos ajenos a los compromisos internacionales..."; o cuando el propio Estado incurre en violaciones flagrantes del orden jurídico, al excluir a sus agentes de la observancia del proceso legal en otros Estados y dar ropaje de legalidad y legitimidad a "...la comisión de delitos bajo el pretexto de la justicia penal, con el argumento male captus bene detentum". ${ }^{41}$

\section{Vinculación del derecho internacional penal con la justicia penal internacional}

Analizando y compartiendo algunos criterios expuestos por Susana Hernández Pacheco, doctora en derecho internacional e investigadora universitaria, en un primer intento por esclarecer esta correlación disciplinaria entre derecho internacional penal y justicia penal internacional, partiremos de la tesis — ya antes referida - de que el orden jurídico internacional está dirigido a los Estados, sujetos originarios y genéricos del derecho internacional; presentándose la situación de que las personas pri-

41 Ibidem, p. 755. El autor pone por ejemplo de este hecho la sentencia de la Suprema Corte de Estados Unidos, del 16 de junio de 1992, dictada en el caso United States vs. Humberto Álvarez Machain, que proyectó su presidente el señor Rehnquist. Para mayor referencia de este interesante caso en particular - por cierto muy difundido por la prensa en sus aspectos superficiales, pero nunca en el fondo ni en su seguimiento jurídico-, me permito recomendar al lector la consulta del libro de la Secretaría de Relaciones Exteriores de México, intitulado: Límites de la jurisdicción nacional. Documentos y resoluciones judiciales del caso Álvarez Machain, México, SRE, 1992. 
vadas sólo pueden invocar una norma del ius gentium cuando el Estado la integra a su derecho interno. Empero — como ya también lo explicamos con cierto detalle en el apartado anterior- hoy existe mayor reconocimiento de personalidad jurídica al individuo, como ocurre cuando los Estados deciden conferirles derechos o imponer obligaciones a las personas físicas en el orden normativo supraestatal. Y aunque se trata de una subjetividad atípica o sui generis y con limitaciones propias de su naturaleza derivativa, el individuo ha sido beneficiario de derechos — sobre todo en materia del régimen de protección internacional de derechos humanosy al mismo tiempo se le han impuesto obligaciones en el ámbito del derecho internacional penal.

Sin necesidad de escudriñar en la historia y la doctrina del derecho internacional, podemos observar que en el pasado se incorporaron a su contenido una serie de normas de carácter penal encaminadas directamente a los individuos. No obstante la práctica de los Estados en materia penal ha sido un tanto dispersa en lo que respecta a la producción normativa — legislación penal — y a la estructuración institucional —organismos jurisdiccionales - Ello lo demuestra el antecedente y la experiencia de los multicitados tribunales militares de Nüremberg y de Tokio y los recientes para la ex Yugoslavia y Ruanda, aunque de distinto orden y trayectoria. En realidad, el derecho internacional penal no ha permitido la creación de un código penal aplicable a los individuos, pero sí ha sido posible constituir el fundamento de una corte penal internacional permanente. ${ }^{42}$

Hasta la fecha, generalmente los Estados han ampliado la jurisdicción de sus tribunales internos y aun legislan sobre las infracciones realizadas por individuos o personas extranjeras, lo cual reflejaría la existencia de un sistema de aplicación indirecta del derecho internacional penal y una especie de "suplencia jurídica" ante la carencia de un tribunal penal internacional en funciones $-\mathrm{y}$ su correspondiente código penal supraestatal - con instancias internas, producto de un acuerdo magno multilateral

42 Hernández Pacheco, Susana, "El derecho penal internacional y el Proyecto de la Comisión de Derecho Internacional de la O.N.U. relativo al Estatuto de un Tribunal Penal Internacional", Revista LEX, México, núm. 4, octubre de 1995, pp. 68-75. La autora señala que, en este contexto, los trabajos de la Comisión de Derecho Internacional obedecen a la necesidad de unificar la calificación de hechos ilícitos en materia penal con la creación de un Código de Crímenes contra la Paz y la Seguridad de la Humanidad y de establecer una jurisdicción penal permanente; y que, en forma paralela, se ha planteado la posibilidad de establecer, en el ámbito de la responsabilidad internacional de los Estados, un régimen de sanción al lado del sistema de reparación que regula las consecuencias por la comisión de hechos ilícitos estatales. 
plasmado en un convenio por escrito que - como de hecho ya lo hace el Estatuto de Roma de 1998- regule situaciones específicas en tiempos y espacios predeterminados.

En torno a la creación de dicha corte penal internacional, estructurada como una institución jurisdiccional supranacional, autónoma y permanente, que aplicaría de manera directa y sustantiva el derecho internacional penal, ha surgido de un tiempo a la fecha la controversia de si debe conformarse en primera instancia dicho cuerpo colegiado y, posteriormente, un código penal internacional, o viceversa. Sobre este particular, autores como Quintano Ripollés, R. Garófalo y Ch. Bassiouni - ya antes citados - mantienen la postura de que el nacimiento de la estructura (corte) debe ser posterior al de la sustancia (código). Nuestra opinión al respecto — sin el ánimo de polemizar ahora por quedar el asunto fuera de los alcances de nuestro trabajo - sería que, si efectivamente, la calificación es la capacidad de analizar los actos para determinar si son jurídicos o no, y de serlo, entonces prevenir sus efectos estableciendo el tipo de ley que se aplicará al caso; entonces, y en este sentido, codificar de manera previa, uniforme y precisa se hace indispensable para subsanar deficiencias que ha presentado en su evolución el derecho internacional penal, el cual debe consolidarse como una disciplina consistente para dar cuerpo y sustancia a la justicia penal internacional, formando ambos un frente común y articulado para precaver y atender de manera eficaz los delitos, crímenes y violaciones en las relaciones internacionales de nuestro tiempo.

Por otro lado, retomando y precisando el tema de los sujetos activos de la conducta delictiva, debe hacerse una primera distinción en cuanto a las personas con capacidad de realizar acciones ilícitas en materia penal internacional; así, es evidente que las transgresiones penales de los individuos son diferentes de los hechos ilícitos de los Estados que han sido calificados como crímenes internacionales. Ciertamente, aunque el derecho internacional regula en principio las relaciones interestatales, el derecho internacional penal se ha dirigido principalmente a los individuos. Tal situación queda demostrada cuando observamos que delitos tales como la piratería, el apoderamiento ilícito de aeronaves, la trata de esclavos, el tráfico ilegal de estupefacientes, la falsificación y el fraude en todas sus acepciones, y más recientemente el terrorismo, el lavado de dinero o los delitos denominados de "cuello blanco" — por mencionar sólo algunos-, han sido tradicionalmente hechos del individuo. 
Empero, a partir de los años setenta se ha comenzado a señalar, cada vez con más insistencia, que los Estados como tales pueden cometer crímenes internacionales. ${ }^{43} \mathrm{Y}$ en realidad la distinción entre hechos ilícitos penales cometidos por los Estados e infracciones penales realizadas por individuos no es definitivamente clara, en razón de que un individuo puede incurrir en tales conductas a título personal — en cuyo caso no cabría duda que el hecho le es imputable - o bien, en tanto órgano de Estado, y en este último supuesto, es ostensible que la disociación entre el Estado y sus órganos plantea una problemática bastante complicada. ${ }^{44}$ Luego entonces, en el discernimiento de esta situación, y para que la responsabilidad penal internacional del individuo sea efectiva, es necesario que el derecho internacional, a través de su rama penal, defina los hechos ilícitos que constituirán las infracciones penales, esto es, el derecho sustantivo.

Varios autores coinciden en afirmar que desde la perspectiva del derecho sustantivo el derecho internacional penal comprende dos tipos de normas:

A) Las resultantes de un conjunto de convenciones internacionales ten-
dientes a definir ciertos hechos ilícitos con el fin de unificar las le-
gislaciones penales nacionales y facilitar la persecución y sanción
de los delitos previstos convencionalmente (sería lo que algunos au-

43 Ibidem, p. 68. La autora señala que en la primera parte de los trabajos de la Comisión de Derecho Internacional sobre el "Origen de la responsabilidad internacional", se estableció una diferencia entre delitos y crímenes internacionales, pretendiendo con ello instaurar al lado del régimen de reparación —que no prejuzga sobre la sanción de un hecho ilícito sino que únicamente tiende a reparar el daño causado-, un sistema de penalización basado en la existencia de crímenes internacionales definidos por el artículo 19 de este proyecto como "un hecho internacionalmente ilícito que resulta de la violación por un Estado de una obligación internacional tan esencial para la salvaguarda de los intereses fundamentales de la comunidad internacional que su violación es reconocida como un crimen por esta comunidad en su conjunto". Y en el comentario de este artículo se enlistan algunos crímenes internacionales, tales como la agresión, el mantenimiento por la fuerza de una dominación colonial, la esclavitud, el genocidio, el apartheid, y los daños graves al medio ambiente humano. E indica nuestra colega que, sin embargo, la propuesta de la CDI de distinguir los delitos de los crímenes internacionales evidencia problemas en los que no se ha podido llegar a un acuerdo (para mayores datos consúltese el Informe de la CDI en su 46o. periodo de sesiones del 2 de mayo al 22 de julio de 1994).

44 Sobre este rubro particular, recordemos que el Tribunal de Nüremberg estableció en sus sentencias emitidas en noviembre de 1946 que: "Los crímenes contra el derecho internacional son cometidos por personas y no por sujetos abstractos, por eso únicamente a través del castigo de los individuos que perpetran tales actos pueden tener aplicación los preceptos del derecho internacional". (Dato corroborado en la Enciclopedia Mundial de Relaciones Internacionales y Naciones Unidas, de Edmund Jan Osmañczyk, México, FCE, 1976, p. 348). 
tores como André Huet y Renée Koerin-Joulin denominan derecho penal internacional).

B) Aquellas disposiciones jurídicas internacionales que consideran que existen ciertos crímenes internacionales cuya gravedad amerita la creación de un tribunal penal internacional para sancionarlos, junto con un código penal específico, para que la justicia penal internacional se materialice (sería lo que en cierta medida consideramos un derecho internacional penal).

Y sostienen que en el primer caso (A), se trata de infracciones internacionales en las que el individuo actúa a título personal; mientras que, en el segundo (B), se consideran las infracciones internacionales realizadas por individuos en su calidad de agentes públicos.

Por lo que concierne a las infracciones internacionales del individuo actuando a título privado, la historia consigna que ciertos hechos de individuos eran tan graves que resultaba necesario considerarlos como infracciones internacionales, por lo que en su mayoría estos grandes delitos han sido definidos y regulados por el derecho internacional convencional. ${ }^{45}$

Respecto a las infracciones internacionales del individuo actuando como agente público, se dispone de un buen cuerpo de normas y antecedentes. Después de la primera conflagración mundial se perfiló una nueva concepción de la responsabilidad penal del individuo, esto es, por inicial ocasión se concibió la disociación entre el Estado y sus agentes, previéndose así la responsabilidad penal internacional de individuos actuando en nombre del Estado. Y lo importante fue que el proceso de internacionalización se llevó a cabo no sólo en la dimensión normativa, sino que se previó una jurisdicción penal internacional para juzgar a los principales responsables en sustitución de los tribunales internos, que conocieron sólo de los infractores menores. ${ }^{46}$

45 Se trata de los siguientes: a) La piratería en alta mar, constituida por actos violentos contra bienes y personas con fines de lucro; b) La trata de esclavos; c) El tráfico ilícito de estupefacientes; d) La interferencia ilícita de la aviación civil internacional, compuesta de tres aspectos: la piratería aérea, la captura ilícita de aeronaves, y actos ilícitos contra la seguridad de la aviación civil internacional, y e) El terrorismo.

46 El primer instrumento internacional que estableció responsabilidad por delitos contra la paz, las leyes y costumbres de la guerra fue el Tratado de Versalles, de 1919, firmado entre las potencias aliadas y asociadas y Alemania, que definía en la parte VII, relativa a las Sanciones (artículos 227 a 230), tres tipos de crímenes: ofensas a la moralidad internacional, ofensas a la sacrosanta inviolabilidad de los tratados y acciones contrarias a los derechos y costumbres de la guerra (consúltese de Seara Vázquez, Modesto, Del Congreso de Viena a la Paz de Versalles, FCPS, UNAM, 1973, p. 167). 
Ubicándonos en tiempos más recientes, en 1991, la CDI de la ONU aprobó provisionalmente en primera lectura el Proyecto de Código de Crímenes contra la Paz y la Seguridad de la Humanidad, donde se define como crímenes:

- La agresión;

— La amenaza de agresión;

- La intervención;

- La dominación colonial y extranjera;

- El genocidio;

- El apartheid;

- La violación sistemática y masiva de los derechos humanos;

- Los crímenes de guerra de gravedad excepcional;

- El terrorismo internacional;

- El tráfico ilícito de estupefacientes, y

- Los daños deliberados y graves al medio ambiente.

Cabe señalar que la definición de estos crímenes fue retomada por la CDI durante el análisis en segunda lectura del Proyecto de Código realizado durante su 470 . periodo de sesiones, en donde se ha planteado la posibilidad de reducir el número de crímenes, de manera que únicamente se incluyan los crímenes especialmente graves. Y aparentemente, hasta la fecha la cuestión se ha mantenido prácticamente en el mismo grado de avance; al menos ésa es la percepción que tenemos a partir de la revisión general que hemos hecho de los últimos tres Informes de la CDI concer-

Durante la II Guerra Mundial, otros instrumentos internacionales plantearon nuevamente la cuestión de la responsabilidad penal por crímenes de guerra. Tal es el caso de la Declaración conjunta de las principales potencias que luchaban contra los países del Eje, del 1o. de noviembre de 1943 publicada en Moscú, que anunciaba su voluntad de castigar a los criminales de guerra. Posteriormente, el 8 de agosto de 1945 se firmó un Acuerdo entre los gobiernos de Estados Unidos, Gran Bretaña, la Unión Soviética y el gobierno provisional de la República francesa, que preveía el procesamiento y castigo de los principales criminales de guerra y el establecimiento de un Tribunal Militar Internacional. Nace así el Estatuto del Tribunal de Nüremberg, que en su artículo 6o. define tres categorías de crímenes que “...dependen de la jurisdicción del Tribunal y entrañan una responsabilidad personal: a) Crímenes contra la paz...; b) Crímenes de guerra, a saber: la violación de las leyes y costumbres de guerra...; c) Crímenes contra la humanidad...”. Así llegamos al 21 de noviembre de 1947, cuando la Asamblea General de la ONU pidió a la CDI (artículo 13 de la Carta) que estableciera un código único de crímenes contra la paz y la seguridad de la humanidad, procediendo a la formulación de dos proyectos de código que no pudieron ser aprobados porque no se contaba con una definición de agresión, lo cual ocurrió en la Resolución 3314 (XXIX) del 14 de diciembre de 1974, con lo que en 1981 la Asamblea General ordenó a la Comisión que prosiguiera con el análisis del proyecto de código de crímenes (Resolución 36/106). 
nientes a sus 480., 49o., y 50o., periodo de sesiones, correspondientes a los años de 1996, 1997 y $1998 .{ }^{47}$

Resumiendo, las distintas corrientes de opinión coinciden en enfatizar que la sanción de los crímenes internacionales es distinta según se trate de personas privadas o de agentes del Estado, siendo la facultad de represión en el primer caso, exclusivamente nacional, y en el segundo, la sanción del individuo como agente público se ha dejado a tribunales penales internacionales. Esta situación ha hecho pensar a varios autores que, sólo en este último supuesto, es posible hablar de derecho internacional penal $\mathrm{y}$ de justicia penal internacional.

\section{UNA EXPRESIÓN ACTUAL DE LA JUSTICIA PENAL INTERNACIONAL: LA CORTE PENAL INTERNACIONAL}

\section{Los antecedentes. El largo camino que nos condujo a Roma}

El desarrollo de la justicia penal internacional es ahora visto desde muy amplios sectores de opinión como una exigencia ética, una necesidad jurídica y un imperativo político. Como otros grandes movimientos de la historia, nada suele ser tan grandioso como una idea cuya hora ha llegado: el momento de avanzar en el camino de la justicia penal internacional. El "camino a Roma" fue largo y sinuoso camino, a menudo contencioso, como difícil ha sido y será el logro de los propósitos de una corte penal internacional permanente que combina valores humanísticos y

47 Hernández Pacheco, op. cit., nota 42, p. 70. Aunque nos encontramos en los umbrales del tercer milenio, hay antecedentes que aunque casi olvidados, cobran actualidad al hacer un recuento objetivo del difícil tránsito de la humanidad hacia un estadio de justicia penal internacional. Nos referimos a las cuatro convenciones de Ginebra del 12 de agosto de 1949, donde se confirma la definición de crímenes de guerra, mientras que la Convención del 26 de noviembre de 1968 los declara imprescriptibles. Asimismo, las "infracciones graves" a las convenciones de Ginebra de 1949 y al Protocolo de Ginebra de 1977 fueron asimiladas a los crímenes de guerra en el artículo 85 el Protocolo Adicional a los Convenios de Ginebra de 1949 (Protocolo I) celebrado el 8 de junio de 1977, relativo a la Protección de las Víctimas de los Conflictos Armados Internacionales. Otros crímenes han sido definidos en instrumentos convencionales específicos, como la Convención sobre la Prevención y el Castigo del Crimen de Genocidio, del 9 de diciembre de 1948 y la Convención Internacional sobre la Represión y Castigo del Crimen de Apartheid, del 30 de noviembre de 1973, que establecen nuevas infracciones calificándolas de crímenes internacionales. Por su parte, el colonialismo se considera prohibido por el derecho consuetudinario, teniendo su origen esta infracción en la Resolución 1514 (XV) de la Asamblea General de la ONU, adoptada en 1960. Asimismo, en su comentario al artículo 19 del proyecto de artículos sobre la responsabilidad del Estado, la CDI ha considerado que "el establecimiento y mantenimiento por la fuerza de una dominación colonial" constituye un crimen internacional. 
consideraciones políticas que no sólo son esenciales al logro de la justicia, la reparación y la prevención, sino también a la preservación, restauración y mantenimiento de la paz en el mundo caótico en que nos desarrollamos y existimos.

A través del tiempo, el punto frágil del derecho internacional ha sido la carencia de mecanismos de coerción, penalización y sanción efectivos. Ello en razón de que se trata — como lo señala Susana Fraidenraij- de un derecho de coordinación y no de subordinación, como es el caso de las legislaciones nacionales, en el cual los Estados son los sujetos activos — que conciben, aprueban y se obligan por las normas - y también pasivos, esto es, quienes las cumplen o eventualmente las incumplen o las violan. Es un sistema jurídico basado en las relaciones entre entidades soberanas, es decir, jurídicamente iguales. Durante muchas décadas, si uno de esos sujetos soberanos violaba alguna de sus obligaciones, la parte agraviada tenía derecho a recurrir a "medidas de respuesta" tales como la retorsión, la represalia o la legítima defensa. Incluso, el derecho de guerra no contemplaba en modo alguno a las víctimas o los delitos cometidos contra ellas, sencillamente porque el derecho internacional clásico no proscribía la guerra. ${ }^{48}$

La historia de la civilización revela que las formas de gobierno, por encima de su nivel de estructuración, desarrollaron instituciones judiciales cuyos propósitos eran mediar, resolver o imponer soluciones a conflictos que perturbaban el orden social. Y si bien es cierto que la mera existencia y funcionamiento efectivo de las instituciones judiciales no implica la creación de condiciones y resultados de orden, estado de derecho, probidad, reparación, prevención, justicia y paz, lo cierto es que sin tales instituciones, estas condiciones y avances no podrían darse, incluso si fueran impuestos por la fuerza. Ésta nunca ha sido un medio satisfactorio para obtener un desarrollo integral de las sociedades, más aún siempre ha devenido en situaciones de ilegalidad e ilegitimidad. Las instituciones judiciales, junto con otros organismos sociales, políticos y económicos, son indispensables para el establecimiento de un status de justicia en el nivel de las sociedades nacionales, y lo mismo ocurre en la sociedad internacional.

Por ello, desde que en el siglo XIX se comenzó a perfilar la idea de un tribunal penal internacional, que complementara y especializara la competencia de la Corte Internacional de Justicia, se pensó en un ente ca-

48 Fraidenraij, Susana, "La Corte Penal Internacional y el derecho internacional humanitario", ponencia presentada en el Seminario de Justicia Penal Internacional, México, Universidad Iberoamericana, campus Santa Fe, 24-28 de febrero de 2000, p. 2. 
paz de traducir los valores morales comúnmente compartidos por la sociedad de Estados, en preceptos aplicados que generaran reacciones positivas en la propia colectividad internacional; en otros términos, se trazaba ya la imagen de una institución que, concebida como la contraparte de la organización política internacional a las instituciones judiciales nacionales, pero con propósitos más amplios, se constituyera en un escenario creíble en el que el drama privado de un caso dado o serie de casos pudieran resolverse públicamente y proyectarse internacionalmente.

Al parecer la propuesta de establecer una sanción penal por un cuerpo judicial permanente ya había sido efectuada en 1864 por Gustave Moynier, uno de los fundadores del Comité Internacional de la Cruz Roja, en el curso de la conferencia diplomática en la que se aprobaría el Convenio de Ginebra para el mejoramiento de la suerte de los militares heridos de los ejércitos en campaña; sin embargo, como otros proyectos en el mismo sentido, éste no se materializó. Otra versión nos remonta al mismo personaje, pero en el año de 1872, cuando — se afirma- Moynier propuso la creación de una corte penal permanente, autónoma y de alcance internacional, en respuesta a los crímenes de la guerra franco-prusiana. ${ }^{49}$

Ya en el siglo que está por terminar, los esfuerzos por establecer una corte penal internacional permanente (CPI) comenzaron con la Sociedad de Naciones (SDN) y continuaron con la Organización de las Naciones Unidas (ONU). Los esfuerzos de la Liga estuvieron vinculados a una corte penal internacional permanente cuya jurisdicción estaba limitada sólo a la exigencia de la Convención sobre Terrorismo de 1937, pero desafortunadamente fracasó debido a la crisis mundial que siguió a la guerra civil española, la invasión de Italia a Abisinia y las políticas agresivas y militaristas de Alemania en la etapa previa a la segunda conflagración planetaria.

Con las Naciones Unidas ya constituidas se buscó ampliar el objetivo de la SDN al proponerse la instauración de una corte penal internacional permanente de competencia más general. Como lo señala el especialista M. Cherif Bassiouni, ${ }^{50}$ estos esfuerzos pueden ser rastreados a lo largo de dos caminos independientes: la codificación de los crímenes internacionales y la elaboración de un proyecto de estatuto para el establecimiento

49 CICC: The International Criminal Court, información preparada por la Coalition for an International Criminal Court (CICC), distribuida en el citado Seminario de Justicia Penal Internacional, UIA, febrero de 2000 (parte de historia).

50 Bassiouni, M. Cherif, "The History of the Draft Code of Crimes Against the Peace and Security of Mankind”, ISR, L. Rev., Nueva York, 27 1-21, UNO, 1993. 
de una corte penal internacional. El hecho es que ambas trayectorias caminaron separadas, aunque hubieran requerido estar integradas. Pero la historia fue así, revelando la falta de voluntad política de los principales poderes mundiales de reunirlas en un esfuerzo coordinado. Esto se evidencia más aún en los cursos disociados que las diversas instituciones de las Naciones Unidas tomaron entre 1947 y 1998.

En 1947, la Asamblea General otorgó el mandato al Comité de Codificación de Derecho Internacional, el predecesor de la Comisión de Derecho Internacional (CDI) de:

1) formular los principios de derecho internacional reconocidos en la Carta del Tribunal de Nüremberg y en la sentencia del Tribunal, y

2) preparar el proyecto del código de delitos contra la paz y la seguridad de la humanidad, indicando claramente el lugar en que concordaría con los principios mencionados en el subpárrafo (a).

En 1949 la CDI comenzó su tarea, se formó un subcomité y se nombró un relator especial para preparar el Proyecto de Código de Delitos Contra la Paz y la Seguridad de la Humanidad. Este título fue cambiado en 1988 por el proyecto de Código de Crímenes contra la Paz y la Seguridad de la Humanidad. Al mismo tiempo, la tarea de formular un proyecto de estatuto para el establecimiento de una corte penal internacional fue asignada a otro relator especial, quien presentó su primer reporte a la CDI en marzo de 1950. Este reporte argumentaba que un código penal sustantivo debía complementarse con un estatuto para una corte penal internacional. Contrario a la lógica y racionalidad de la política de elaboración de este tipo de preestructuras jurídicas, los proyectos en cuestión quedaron intencionalmente separados. Así, ese mismo año se nombró otro relator para estudiar el ulterior desarrollo del asunto, resultando al final que ambos relatores difirieron por cuanto a si el tiempo era el más apropiado para una corte penal de las características planteadas. No obstante, se estableció un Comité Especial de la Asamblea General compuesto por representantes de diecisiete Estados, con el propósito de redactar una convención para tal efecto, concluyendo en 1951, y diseñando el estatuto en parte sobre la base del de la Corte Internacional de Justicia. Las discusiones y comentarios escritos, particularmente aquellos de las principales potencias, indicaron claramente que el proyecto no tenía oportunidad de 
aceptación y era políticamente prematuro. ${ }^{51}$ Debido a que estos Estados no quisieron asumir la responsabilidad política de cerrar la posibilidad de la corte penal internacional, se extendió el mandato del Comité, con algunos cambios en los Estados miembros, y en 1953 se produjo un texto revisado. En esta nueva versión se notaba la presión política, al incorporar disposiciones que limitaban la jurisdicción y permitían a los Estados partes mantener mayor control; también incluía un precepto expreso sobre la prerrogativa de los Estados de denunciar la jurisdicción una vez conferida a la Corte, es decir, borraron el requerimiento de que dicha jurisdicción fuera aprobada por la Asamblea General. ${ }^{52}$

La cuestión es que el proyecto de Corte se pospuso hasta que el Proyecto de Código de Delitos — que consistía en cinco artículos que listaban 13 crímenes internacionales separados - se terminara en 1954; empero, éste también fue pospuesto hasta que se pudiera definir "agresión". La razón de esta incoherente situación fue que la Asamblea General en 1950 había retirado el tema de "agresión" del mandato de la CDI para elaborar el Proyecto, y le había dado la tarea a un comité especial dependiente de ella, al cual se le cambió el mandato en 1952, y luego en 1954, y le tomó veinte años llegar a una definición del tema, en 1974. Pero de aquí hasta 1978, la Asamblea no retomó el tema del Proyecto en su agenda hasta que los esfuerzos de un buen grupo de Estados y de organizaciones no gubernamentales la forzaron en ese sentido, procediendo a ordenar a la CDI para trabajar en la materia. En 1982, un nuevo relator de la CDI produjo su primer reporte, que contenía varias generalidades respecto al derecho internacional penal, la responsabilidad individual y estatal y observaciones sobre los eventuales contenidos de tal código, y como se trataba de un trabajo ab initio, le tomó hasta 1991 producir lo que intentaba ser un texto final; empero, como fue criticado por gobiernos y académicos fue revisado y adoptado por la CDI hasta 1996.

51 Ibidem, p. 17. Mientras que algunos gobiernos creían que el establecimiento de una corte penal internacional era teoría deseable, siempre fueron escépticos sobre su éxito en vista de la ausencia de consenso entre las principales potencias mundiales. La Unión Soviética creía que su soberanía sería afectada; Estados Unidos se decía no estar preparado en la cresta de la "guerra fría"; Francia expresaba su apoyo, pero no impulsaba el proceso, y el Reino Unido veía la idea como políticamente prematura.

52 Otros argumentos que incluso hoy día se siguen esgrimiendo contra la idea del funcionamiento pleno de una corte penal internacional son, entre otros: los conflictos de las políticas nacionales, las prohibiciones constitucionales, las normas divergentes, la pluriconceptuación de la seguridad estatal, las tesis y posturas soberanas, los principios encontrados del derecho internacional, la inexistencia de un código penal internacional acabado y un derecho internacional penal en etapa de precariedad. 
Mientras tanto, el proyecto de una CPI había quedado estancado. Y el resultado era esperable, ya que había diferentes organismos trabajando en forma separada en distintos lugares (Ginebra y Nueva York), y produciendo textos diferentes en distintos momentos. Era, entonces, fácil para la Asamblea General posponer cada texto sucesivamente debido a que uno y otro proyectos no estaban listos. A nuestro modo de ver, esa falta de sincronización no era enteramente fortuita: resultaba directamente de la voluntad política de demorar el establecimiento de esa instancia judicial debido a que se vivían tiempos en que el mundo estaba marcadamente dividido y frecuentemente en riesgo de guerra. En realidad, hasta ese momento sólo dos convenciones internacionales se referían a una jurisdicción penal internacional, a saber: el artículo 6o. de la Convención sobre Genocidio de 1948 y el artículo 5o. de la Convención sobre el Apartheid de 1973. La primera, sin embargo, sólo se refería a la jurisdicción sobre genocidio de una eventual corte penal internacional; mientras la segunda apuntaba la instauración de ese cuerpo para juzgar el apartheid, pero no se estableció.

En este devenir, el año de 1989 es clave, después de una interrupción de 26 años. Por un lado, el fin de la guerra fría lleva a un notable incremento del número de las operaciones de las Naciones Unidas para el mantenimiento de la paz y a un reacomodo del sistema político mundial y, por el otro, la Asamblea General sostuvo una sesión especial sobre el problema del tráfico de drogas, y Trinidad y Tobago sugirió la creación de una CPI especializada. Luego de ello, la Asamblea General solicitó que la CDI preparara un informe sobre el establecimiento de una CPI para el enjuiciamiento de personas involucradas en el tráfico de drogas. Paralelamente, un comité de expertos preparó un proyecto de estatuto para una CPI que tendría jurisdicción sobre todos los crímenes internacionales, y cuyo texto fue sometido al Octavo Congreso de las Naciones Unidas sobre Prevención del Crimen y el Tratamiento de los Transgresores, que reconoció la necesidad de dicho tribunal y recomendó que la CDI retomara el tema. Así lo hizo, ampliándose su mandato para preparar un estatuto con mayor cobertura en 1993 y que fue modificado en 1994.

Paralelamente, se estaban presentando varios hechos que impulsaron abiertamente la creación de una CPI: $a$ ) la guerra en Bosnia-Herzegovina, las claras violaciones a la Convención del Genocidio, las Convenciones de Ginebra y la creación de un tribunal ad hoc para Yugoslavia (1993); b) la Declaración y el Programa de Acción de Viena (junio de 1993); c) la 
guerra en Ruanda conduce al Consejo de Seguridad a establecer un segundo tribunal ad hoc para hacer justicia ante el genocidio cometido en dicho país, y $d$ ) la CDI presenta un proyecto final de estatuto sobre la CPI a la Asamblea General y recomienda que una conferencia de plenipotenciarios sea convocada para negociar un tratado para promulgar dicho instrumento, estableciéndose un comité ad hoc con tal encomienda. No obstante, en esta resolución la Asamblea General desvincula el proyecto de estatuto de la CPI de 1994 de su proyecto de Código de Crímenes contra la Paz y la Seguridad de la Humanidad de 1991.

Ya para 1995, el comité ad hoc celebra tres reuniones de dos semanas en la sede de las Naciones Unidas, y en diciembre, la Asamblea General establece un Comité Preparatorio (Prep-Com) para finalizar un proyecto de estatuto a ser presentado en una reunión de plenipotenciarios. Así, entre 1996 y 1998 el Prep-Com se reúne seis veces para continuar con la importante tarea. Llegamos entonces al año de 1997, cuando ocurren dos hechos importantes: a) los catorce Estados miembros de la Comunidad para el Desarrollo Sudafricano (SADC) establecen diez principios básicos a ser incluidos en la formación del estatuto de la CPI, y $b$ ) el Reino Unido se aleja de la posición de los otros miembros del Consejo de Seguridad y respalda la Propuesta de Singapur encaminada a limitar la autoridad del Consejo de Seguridad sobre la CPI.

Como es de sobra conocido, el año de 1998 es clave en esta larga historia. Los hechos a destacar, sin demérito de otras acciones también de relevancia, son los que a continuación se enuncian:

- En enero, los jefes de los grupos de trabajo y coordinadores del Prep-Com se reúnen en Zutphen, Holanda, "para facilitar el trabajo de la última Prep-Com”. El Informe Zutphen consolida los diferentes proyectos de texto producidos en los dos años de reuniones.

- En febrero, en Dakar, Senegal, representantes de 25 gobiernos africanos se reúnen para discutir la creación de una CPI. Deciden adoptar entonces la Declaración de Dakar llamando a una "Corte Penal Internacional eficaz e independiente".

- En mayo, en una carta a la secretaria de Estado, Madeleine Albright, el presidente del Comité de Relaciones Exteriores del Senado de los Estados Unidos, Jesse Helms, declara que cualquier estatuto de la CPI estará "muerto al llegar" al Senado, a menos que el Estado norteamericano tenga poder de veto sobre la Corte. 
Esto provocó una sólida reacción en contra por parte de la comunidad de Estados proclives, que continuaron su largo camino a Roma.

— Entre el 15 de junio y el 17 de julio, en Roma, Italia, 160 países participan en la Conferencia Diplomática de Plenipotenciarios de las Naciones Unidas sobre el Establecimiento de una Corte Penal Internacional, con carácter permanente y autónomo.

- El 17 de junio, un total de 120 Estados miembros de la ONU votan abrumadoramente a favor del Estatuto de Roma que establece una CPI, con solamente siete votos en contra y registrándose veintiún abstenciones.

En tiempos más actuales, el 2 de febrero de 1999, Senegal se convierte en el primer Estado parte en ratificar el Estatuto de Roma, siguiéndole en orden Trinidad y Tobago, San Marino, Italia, Ghana, Fiji, Noruega, Tajikistán, Venezuela, Francia, Lesotho, Sierra Leona, Belize, Nueva Zelanda, Luxemburgo, Islandia, Canadá, Bélgica y Botswana. Asimismo, la Asamblea General convocó a una serie de reuniones adicionales del PrepCom para elaborar los proyectos del texto sobre las Reglas de Procedimiento y Prueba y los Elementos del Crimen, las que se verificaron el 16 al 26 de febrero, del 26 de julio al 13 de agosto y del 29 de noviembre al 17 de diciembre. ${ }^{53}$

Y en el presente año 2000 ya se realizaron dos sesiones con el mismo propósito, una del 13 al 31 de marzo y la otra del 12 al 30 de junio, y cuyos resultados se consignarán en una posterior contribución. Finalmente, quisiéramos mencionar el status de firmas y ratificaciones al Estatuto de Roma actualizado al 10 de octubre de 2000:

- Países firmantes: 112 (México lo hizo el 7 de septiembre de 2000).

- Países con ratificación: 21.

53 Toda la información y datos mencionados a lo largo de las últimas páginas fueron obtenidos de los Reportes Oficiales de la Coalition for an International Criminal Court (CICC), op. cit. Además, se bajó información reciente de la internet visitando el sitio: http://www.un.org./law/icc/statute/status.htm. 


\section{Estructura y funciones de la Corte Penal Internacional conforme al Estatuto de Roma}

Tomando las palabras de Bruce Broomhall,${ }^{54}$ el Estatuto de Roma representa un balance entre los roles de instituciones nacionales e internacionales. Está elaborado sobre el principio propuesto por la CDI de que la CPI debería funcionar esencialmente como un incentivo y como complemento a las jurisdicciones nacionales. Concebido como tratado multilateral, el Estatuto requerirá seguramente un amplio apoyo para disuadir, prevenir o castigar apropiadamente el genocidio, los crímenes de lesa humanidad y los crímenes de guerra. Está diseñado para atraer su apoyo sin sacrificar la justicia y efectividad de la Corte como institución. Coincidiendo con Broomhall, pensamos que el instrumento logra ambos objetivos a través de una combinación de características. Por ahora, sus temas de competencia son relativamente estrechos, consistiendo, como sabemos, en sólo tres crímenes, y su jurisdicción tiene cobertura únicamente para conductas que ocurran a posteriori de la entrada en vigor del Estatuto.

Cabe señalar que los procedimientos de admisibilidad definen cuidadosamente la relación entre la CPI y las competencias nacionales. En este sentido, los sistemas legales de los Estados conllevarían la responsabilidad principal para las investigaciones y enjuiciamiento de crímenes de mayor preocupación para la sociedad internacional; de hecho, la contribución de la Corte para lograr justicia a través de administraciones nacionales de justicia parece ser el logro más significativo a largo plazo. La CPI sólo podrá admitir aquellos asuntos que los Estados le cedan voluntariamente o estén de otro modo inactivos, o cuando sean incapaces o no estén dispuestos realmente a proceder. Y aun en este supuesto, la Corte tendrá capacidad de ejercer su competencia exclusivamente cuando el Estado cuyo súbdito o nacional, o en cuyo territorio se haya cometido la conducta ilícita sea parte, o haya reconocido la competencia de la CPI para tratar la cuestión.

Más todavía, los procedimientos de competencia de la Corte permiten un aplazamiento a los procedimientos del Estado en una serie de si-

54 Broomhall, Bruce, La Corte Penal Internacional: visión general, y la cooperación con los Estados, traducido por la APRODEH, LLB University of British Columbia, 1996, pp. 45-55. El autor es fundador de la Sociedad Internacional de la Corte Penal y participó en la Conferencia Diplomática de Roma, acreditado tanto por el Centro Internacional para la Reforma Legal Penal y la Política de Justicia Penal y la Asociación Internacional de Derecho Penal. Se le puede contactar por correo electrónico en: brucemb@hotmail.com. 
tuaciones que establece el propio Estatuto. Al mismo tiempo, además de la facultad de los Estados partes y del Consejo de Seguridad (conforme al capítulo VII de la Carta de las Naciones Unidas) de someter situaciones a la Corte (como lo sugirió la Comisión de Derecho Internacional), está la facultad del fiscal de actuar desde su propia iniciativa — una especie atípica de habeas corpus internacional-, sujeto a garantías, la que le asegura a la CPI un rol cuando se requiera.

Existe otra serie de disposiciones de cooperación detalladas en el Estatuto que, de entrada, propenden a una instancia jurisdiccional eficaz, en tanto que permiten modalidades de cooperación de acuerdo con el derecho interno. Garantías al debido proceso, procedimientos de apelación, y apoyo institucional para la independencia e imparcialidad, aseguran a los Estados partes y a las personas acusadas la regularidad y objetividad que se requiere en el estado de derecho internacional.

Ahora bien, antes de pasar a revisar de manera breve y general su estructura y funcionamiento, cabe advertir que el Estatuto de Roma es un instrumento de técnica jurídica compleja, extenso y sofisticado, por lo que ningún resumen proveerá un mejor conocimiento de la Corte que el estudio profundo y detallado del Estatuto mismo, lo cual, por las razones al principio ya expuestas, rebasa el objetivo y los alcances de la presente investigación. Al mismo tiempo, habrá que considerar el hecho de que el régimen de la CPI puede resumirse en un amplio perfil a la luz del propósito y principios que se encuentran detrás de su establecimiento y exis-tencia.

\section{Sede, órganos y funcionarios elegidos}

El diseño de la Corte le provee de estructuras y procedimientos para asegurar eficacia, la mayor competencia posible, equidad e imparcialidad hacia los Estados partes y las personas que comparecerán ante la misma. Los Estados partes controlan la elección inicial de los magistrados, el fiscal, y cualquier fiscal adjunto. Estos funcionarios de alta jerarquía son regulados por una combinación de altas calificaciones, niveles de desempeño en sus funciones y procedimientos para garantizar la independencia e imparcialidad, incluyendo aquellos para la descalificación y remoción del cargo.

\section{a. Sede y órganos}

A diferencia de los tribunales ad hoc que le antecedieron, la CPI será una institución permanente. Su sede se establecerá en Holanda, en La 
Haya, y se definirán acuerdos formales para definir sus relaciones tanto con el Estado sede como con las Naciones Unidas. La Corte se integrará por los siguientes órganos:

- Los magistrados, inicialmente constituidos en número de dieciocho, organizados bajo una presidencia responsable de la administración adecuada de la Corte.

- Las secciones de cuestiones Preliminares, de Apelaciones, y de Primera Instancia.

- La Oficina del Fiscal, que es un órgano independiente.

- Los fiscales adjuntos.

- La Secretaría, encabezada por el secretario, jefe administrativo de la CPI.

- La Asamblea de Estados partes, que llevará a cabo la gerencia de supervisión, la elección de los magistrados y otras funciones importantes.

\section{b. Los magistrados, las secciones de la Corte, la presidencia}

Los magistrados serán elegidos por nueve años en términos no renovables. No habrá dos del mismo Estado parte. Tendrán "alta consideración moral, imparcialidad e integridad", y al menos nueve serán de reconocida competencia en derecho y procedimiento penales, y al menos cinco tendrán notable conocimiento de derecho internacional, tales como derechos humanos y derecho humanitario, con una importante y amplia experiencia profesional legal. En su elección se buscará que representen los principales sistemas legales y regiones geográficas del mundo, y una justa proporción entre magistrados hombres y mujeres.

La presidencia estará integrada por tres jueces que desempeñarán su cargo en régimen de dedicación exclusiva tan pronto como sean elegidos. El Estatuto señala un procedimiento para incrementar el número de magistrados cuando así sea requerido. La presidencia y otros cuatro magistrados formarán la Sección de Apelaciones, donde se desempeñarán durante nueve años. No menos de seis jueces conformarán la Sección de Primera Instancia, que desempeñará su trabajo a través de una o más salas de primera instancia de tres magistrados. Por su parte, la denominada Sección de Cuestiones Preliminares jugará un amplio papel en la conducción de las investigaciones, y consistirá de no menos de seis magistrados ejerciendo sus funciones en las Salas de Cuestiones Preliminares con tres 
jueces o uno, dependiendo de la función que se ejerza. Cada sección contiene una combinación apropiada de experiencia en derecho penal y procedimiento y derecho internacional, y en estas dos últimas la duración en el cargo es de tres años, aunque la presidencia puede asignar a un magistrado o magistrados de una de estas secciones a otra si la gestión eficiente del trabajo de la CPI así lo amerita. Estos funcionarios judiciales serán independientes en el ejercicio de sus funciones y no realizarán actividad alguna que pueda ser incompatible con dicho ejercicio o poner en duda su imparcialidad.

\section{c. El fiscal}

La posibilidad — que ya es una realidad - de que el fiscal pudiera recibir la facultad de iniciar investigaciones motu propio concentró la atención de los delegados a la conferencia diplomática. Las consecuencias fueron no sólo garantías que incluyen el aplazamiento al procedimiento estatal y los procedimientos y la supervisión de la Sala de Cuestiones Preliminares, sino también requisitos rigurosos para las calificaciones e independencia del fiscal.

La Oficina del fiscal es un órgano independiente de la Corte, responsable de recibir remisiones e información corroborada que pudiera iniciar una investigación y finalmente el enjuiciamiento por la CPI. Está dirigida por el fiscal, quien estará asistido por uno o más fiscales adjuntos. Está facultado para nombrar asesores jurídicos especialistas en determinados temas, incluyendo violencia sexual y de género y de violencia contra los niños. El fiscal y los fiscales adjuntos serán personas que gocen de "alta consideración moral" y serán altamente competentes y con una extensa experiencia en el ejercicio de la acción penal o la sustanciación de causas penales. Serán elegidos en votación secreta y por mayoría absoluta de los miembros de la Asamblea de Estados partes, y desempeñarán sus cargos en régimen de dedicación exclusiva por un periodo no renovable de nueve años y serán de diferentes nacionalidades.

Los miembros de la Oficina tienen prohibido buscar o actuar según instrucciones de ninguna fuente externa, no participarán en ningún asunto que pueda interferir con sus funciones o menoscabar la confianza en su independencia; tampoco podrán ejercer otra ocupación de carácter profesional o cualquier actividad que ponga en duda su imparcialidad. La presidencia puede aceptar una petición del fiscal o fiscal adjunto de ser dis- 
pensados de intervenir en una causa determinada; de otro modo, la Sala de Apelaciones puede decidir otra recusación.

\section{d. La Secretaría}

La Secretaría estará encargada de los aspectos no judiciales de la administración de la CPI y estará a cargo del secretario, su jefe administrativo, y, si fuera necesario, de un secretario adjunto. El Estatuto atribuye a la Secretaría el manejo de una Dependencia de Víctimas y Testigos para brindarles medidas de protección y dispositivos de seguridad, asesoramiento y otro tipo de asistencia; amén de contar con personal especializado para atender a las víctimas de traumas, y aconsejará al fiscal y a la Corte respecto a medidas y asistencia apropiadas. El secretario y cualquier secretario adjunto serán elegidos en votación secreta por mayoría absoluta de los magistrados, a recomendación de la Asamblea. Se desempeñarán en la función cinco años, que podrán renovarse por una vez, en régimen de dedicación exclusiva.

$e$. Separación del cargo; privilegios e inmunidades

Cualquier alto funcionario de la CPI podrá ser separado del cargo debido a una falta grave de las funciones que le confiere el Estatuto o por una incapacidad de ejercerlas. En el caso de un magistrado, la decisión de separar del cargo será adoptada por la Asamblea por una mayoría de dos tercios (con la recomendación aprobada por mayoría de dos tercios de los demás magistrados). En el caso del fiscal (o por recomendación del fiscal, de un fiscal adjunto), la separación del cargo requiere de una mayoría absoluta de los Estados partes. El secretario y el secretario adjunto se pueden separar por una mayoría absoluta de magistrados. Se disponen también otras medidas disciplinarias por faltas menos graves.

Para garantizar una mayor capacidad de ejercicio eficaz de la Corte, el Estatuto dispone que los magistrados, fiscales, fiscales adjuntos y secretario gocen de los mismos privilegios e inmunidades acordados para los jefes de misiones diplomáticas cuando actúen en el desarrollo de sus funciones. La inmunidad se hará extensiva respecto a las declaraciones orales o escritas y actos realizados en la ejecución de sus funciones oficiales. Asimismo, se establecen procedimientos para la renuncia a privilegios e inmunidades. 


\section{f. La Asamblea de Estados partes}

Es el foro multilateral donde se toman decisiones clave que influyen en la vitalidad y efectividad de la Corte, de tal suerte que los Estados partes que participen en ella jugarán un papel importante en la promoción del derecho internacional general y penal y en la ampliación de los efectos del Estatuto en la sociedad internacional. Su estructura y funciones están diseñadas por la carta constitutiva de la CPI, de modo que se brinde a los Estados partes una facultad efectiva de supervisión sin afectar la independencia del tribunal. La ratificación otorga el derecho a ser parte de la Asamblea de Estados Partes. Cada Estado tiene un representante (acompañado de suplentes o asesores) con la prerrogativa de voz y voto.

Los Estados que hayan firmado el Estatuto o el acta final, pero no hayan ratificado, podrán participar a título de observadores (sin el derecho a voto). La Asamblea se iniciará con al menos sesenta miembros - ya que este es el número requerido para la entrada en vigor del Estatuto-, y tendrá una mesa de dieciocho miembros, incluyendo un presidente y dos vicepresidentes, elegidos por la Asamblea por periodos de tres años. La Asamblea y la mesa se reunirán al menos una vez por año, y la presidencia de la Corte, el fiscal y el secretario podrán participar. Se pueden convocar periodos extraordinarios, y las decisiones tanto de la Asamblea como de la mesa se tomarán por consenso en lo posible y, a falta de éste, se decidirán las cuestiones de fondo por mayoría de dos tercios y las de procedimiento por mayoría simple de los Estados partes presentes y votantes.

Este órgano parlamentario tiene asignadas importantes tareas. Después de adoptar sus propias reglas de procedimientos, en la primera sesión examinará y aprobará, según proceda, los proyectos que la Comisión Preparatoria le presente, incluyendo, esencialmente, las reglas de procedimiento y prueba y los elementos del crimen. Además de elegir a los magistrados, el fiscal y fiscales adjuntos, y recomendar a los magistrados a candidatos para el puesto de secretario y secretario adjunto la Asamblea, en los términos del párrafo 2 del artículo 112:

b) Ejercerá supervisión respecto de la presidencia, el fiscal y la Secretaría en las cuestiones relativas a la administración de la Corte;

c) Examinará los informes y actividades de la mesa... y adoptará las medidas que procedan a este respecto;

d)Examinará y decidirá el presupuesto de la Corte;

e) Decidirá si corresponde... modificar el número de magistrados; 
f) Examinará cuestiones relativas a la falta e cooperación;

g) Desempeñará las demás funciones que procedan en virtud del presente Estatuto y las Reglas de Procedimiento y Prueba.

Sobre el inciso f), la Asamblea se responsabilizará de asegurar la efectividad de la Corte en su rol clave de ejecutora de último recurso. También podrá establecer órganos subsidiarios, incluido un mecanismo independiente de supervisión para mejorar la eficiencia y economía de la CPI; y es también responsable de las enmiendas al Estatuto. ${ }^{55}$

\section{Temas materia de competencia}

El Estatuto otorga competencia a la CPI sólo respecto a los “crímenes más graves de trascendencia para la comunidad internacional en su conjunto". Conforme al principio de legalidad, la Corte únicamente tendrá potestad sobre los crímenes definidos en el Estatuto, y sólo cuando se cumplan todas las otras condiciones previas para la competencia y admisibilidad, es decir, al menos inicialmente, el genocidio, los crímenes de lesa humanidad y los crímenes de guerra.

\section{A. Genocidio}

La definición de genocidio del Estatuto adopta literalmente el de la Convención sobre el Genocidio de 1948. Este crimen puede ser perpetrado por actores oficiales o no estatales, y en tiempo de paz o de conflicto armado internacional o no internacional. Ocurre genocidio cuando se comete cualesquiera de las cinco acciones listadas "con la intención de destruir, total o parcialmente a un grupo nacional, étnico, racial o religioso como tal". Esta intención específica es la esencia de este crimen: cuando no está presente, los actos, cuando proceda, pueden sumarse a crímenes de lesa humanidad o crímenes de guerra. Las acciones son matanza o lesiones graves físicas o mentales a miembros del grupo, sometimiento intencional al grupo a condiciones de existencia que hayan de acarrear su

55 Mientras que la mayoría de formas de enmienda al Estatuto requieren de ratificación a nivel nacional antes de entrar en vigor, la adopción y enmienda de las Reglas de Procedimiento y Prueba, los Elementos del Crimen, las Reglas y Reglamentaciones Financieras y otros instrumentos inicialmente preparados por la Comisión Preparatoria no lo requieren. Tampoco lo requiere la adopción del presupuesto u otras tareas señaladas en el párrafo 2 del artículo 112. El Estatuto anticipa, entonces, que estas decisiones de la Asamblea de los Estados partes sean legalmente vinculantes en el ámbito nacional, dando un papel cuasi-legislativo a los representantes de los gobiernos en la Asamblea. 
destrucción física total o parcial, medidas destinadas a impedir nacimientos en el seno del grupo y traslado por la fuerza de niños del grupo a otro grupo. Cada una de estas acciones se refiere a más de una persona; así, el genocidio conlleva la idea de un ataque a más de un individuo. No obstante, no se requiere de un ataque masivo o un intento a gran escala que pretenda destruir a un grupo para definir el crimen. Tampoco se necesita de un plan o política como tal, sea estatal o relativo a otro organismo. La escala del ataque o intento de ataque, la presencia de un plan o política, y la existencia de un conflicto armado, sería indudablemente examinado por la Corte, sin embargo, cuando es tomado en cuenta es para determinar si el crimen fue suficientemente grave como para justificar el ejercicio de su competencia.

\section{B. Crímenes de lesa humanidad}

Estos crímenes han sido reconocidos desde el Tratado de Versalles, pero recibieron su primera confirmación definitiva en la Carta del Tribunal de Nüremberg. No han sido también definidos en instrumentos multilaterales desde ese tiempo, aunque aparecieron en los estatutos de los tribunales penales de la antigua Yugoslavia y de Ruanda. Consecuentemente, como resultado del desarrollo tanto del derecho internacional consuetudinario y convencional, el componente relevante que establece esta categoría ha sido sometido a un esclarecimiento considerable antes de la adopción del Estatuto. Los crímenes de lesa humanidad se pueden perpetrar en tiempo de paz o en tiempo de conflicto armado, sea internacional o no, por actores estatales o no estatales. Comprenden cualesquiera de las once acciones listadas realizadas como parte de un ataque más amplio y sistemático (lo que supone una línea de conducta y no sólo un incidente aislado) dirigido contra la población civil. El ataque debe "cometerse de conformidad con o para promover una política de un Estado o de una organización".

Los actos están explicados o definidos en el artículo 7 (excepto el asesinato), y son:

- Asesinato

- Exterminio

- Esclavitud

- Deportación o traslado forzoso de población

- Encarcelación u otra privación grave de la libertad 
- Tortura

- Violación, esclavitud sexual, prostitución forzada, embarazo forzado, esterilización forzada u otros abusos sexuales de gravedad comparable

- Persecución de un grupo o colectividad con identidad propia

- Desaparición forzada de personas

- El crimen del apartheid

- Otros actos inhumanos de carácter similar que causen intencionalmente grandes sufrimientos o atenten gravemente contra la integridad física o la salud mental o física.

Tales actos, atroces en sí mismos, deben acompañarse de la prueba de que la persona a cargo tenía conocimiento del ataque. Este requerimiento de conocimiento, así como el de la presencia de un plan o política y de acciones múltiples, deja claro que estos crímenes tienen un umbral elevado y que la competencia de la Corte es por tanto limitada.

\section{Crímenes de guerra}

Se dividen en aquellos perpetrados en conflicto armado internacional y en conflicto armado no internacional; están antiguamente reconocidos y extensamente detallados. La vasta mayoría de prohibiciones en el Estatuto se originan en los convenios internacionales reunidos en las leyes de La Haya y los Convenios de Ginebra, mientras que el resto son ejemplos o analogías de aquéllas. De hecho, varios de estos crímenes enumerados están formulados más cuidadosamente que en su forma convencional original. El Estatuto divide a los crímenes perpetrados en conflicto armado internacional en las seis Infracciones Graves de las Convenciones de Ginebra de 1949 (contra personas protegidas - los heridos, enfermos y náufragos, prisioneros de guerra, civiles - tal como se definen en los convenios) y veintiséis otras serias violaciones a las leyes y usos aplicables en los conflictos armados internacionales. Aunque son demasiado numerosos para señalarlos todos, los ejemplos de los crímenes pueden agruparse en las siguientes categorías:

- Trato de personas

- Trato de plazas y bienes

- Fiscalización para el ataque de plazas y bienes

- Métodos y medios de guerra. 
Las prohibiciones relativas al conflicto armado interno también se dividen en dos. Se listan cuatro violaciones graves del artículo 3 común del Convenio de Ginebra de 1949, cometidos contra personas que no participen en las hostilidades. Las disposiciones restantes sobre conflicto armado interno - que pueden ser cometidos por actores estatales o no estatales en conflictos "prolongados" entre el gobierno y grupos armados o entre tales grupos - se derivan de la legislación consuetudinaria basada principalmente en el Protocolo Adicional II a los Convenios de Ginebra de 1949. Se listan doce prohibiciones similares a aquellas para conflictos armados internacionales.

Estas normas no se aplican a disturbios internos y tensiones internas tales como motines, actos aislados y esporádicos de violencia. Tampoco afectan la responsabilidad del gobierno de restablecer el orden público y de defender la unidad e integridad territorial del Estado por cualquier medio legítimo.

Los crímenes de guerra, a los efectos del Estatuto, no necesariamente requieren plan o política estatal o de una organización. Empero, trátese de conflicto internacional o interno, la Corte será competente sobre crímenes de guerra "en particular cuando se cometan como parte de un plan o política o como parte de la comisión a gran escala de tales crímenes". La presencia de tal plan o política, o una acción a gran escala, será indudablemente revisada por la CPI para determinar si el crimen en cuestión es suficientemente grave como para ser admisible.

\section{El crimen de agresión}

Se incluye en la lista de los crímenes de la competencia de la Corte, pero al mismo tiempo, muchos Estados consideraron muy importante dejarlo fuera de tal jurisdicción. De hecho, los Estados en la Conferencia Diplomática no pudieron llegar a un consenso sobre una definición. Como resultado, la CPI no ejercerá competencia sobre este crimen hasta que se adopte una disposición usando los rigurosos procedimientos de enmienda aplicables a la adición de nuevos crímenes, lo que debe esperar por lo menos siete años después de que el Estatuto entre en vigor.

La formulación de una propuesta de dispositivo está a cargo de la Comisión Preparatoria. Se establecerá una definición junto con las condiciones bajo las que se puede ejercer competencia. El Estatuto afirma expresamente que cualquier disposición sobre el crimen de agresión debe ser 
compatible con la Carta de Naciones Unidas; y muchos Estados interpretan que la "compatibilidad" requiere de una condición previa en la que el Consejo de Seguridad, actuando conforme al capítulo VII de la Carta de las Naciones Unidas, constate primero que ha ocurrido una acción de agresión.

\section{E. Crímenes de tratados}

Hubo un apoyo considerable en la Conferencia Diplomática para incluir crímenes basados en tratados relacionados con el terrorismo y tráfico de drogas en el ámbito competencial de la Corte, pero no se pudo llegar a un consenso sobre las definiciones y las condiciones previas adecuadas en el tiempo disponible. Sin embargo, una resolución anexa al acta final recomienda que en la Conferencia de Revisión "se examinen los crímenes de terrorismo y los relacionados con las drogas con miras a llegar a una definición aceptable y a que queden comprendidos en la lista de crímenes de la competencia de la Corte". La primera conferencia será convocada siete años después de la entrada en vigor del Estatuto.

\section{F. Elementos del crimen}

Los elementos del crimen ayudarán a la Corte en su interpretación y aplicación de definiciones de crímenes dentro del Estatuto. Son un instrumento complementario que establecerá en detalle los elementos materiales y mentales de los crímenes dentro del tema materia de competencia de la Corte. Los elementos se adoptarán (y más tarde enmendarán) por una mayoría de dos tercios de los miembros de la Asamblea de Estados partes. El Proyecto de los Elementos será elaborado por la Comisión Preparatoria.

\section{Principios generales}

Los Estados que participaron en el proceso que condujo a la Conferencia Diplomática, y en la Conferencia misma, dieron un lugar prioritario a asegurar que el Estatuto expresara con suma claridad las circunstancias bajo las cuales un individuo puede ser imputado penalmente por uno de los crímenes de la competencia de la Corte. Como resultado, ahí se establecen los principios generales más importantes del derecho penal, y refleja las contribuciones de un amplio rango de países, así como las más 
avanzadas normas internacionales. Por su parte, los principios y normas relacionados con la investigación y enjuiciamiento están contenidos en otras partes del Estatuto.

\section{A. Responsabilidad penal}

La CPI está en capacidad de imputar responsabilidad penal individual sobre personas que hayan cometido crímenes de la competencia de la Corte, no incluyéndose personas legales como los Estados, las compañías $\mathrm{u}$ otros. Los elementos materiales del crimen deben haberse cometido con intención y conocimiento. Una persona será penalmente responsable y podrá ser sancionada conforme a una serie de supuestos que enumera el artículo 25, fracción 3, y estas categorías de responsabilidad serán oportunas para los esfuerzos de los Estados partes en implementar el Estatuto. Los individuos menores de dieciocho años al momento de la presunta comisión de un crimen de la competencia de la Corte están excluidos, y deberán someterse entonces a los procesos del derecho interno.

El Estatuto se aplica por igual a todas las personas sin distinción basada en el cargo oficial (sea jefe de Estado, miembro del gobierno o del Parlamento, etcétera). Asimismo, la Corte no puede ser impedida de ejercer su acción sobre funcionarios de un Estado parte requerido por inmunidades o normas de procedimiento especiales que conlleve el cargo oficial con arreglo al derecho interno o al derecho internacional.

Un jefe militar (o un jefe no militar actuando como tal) es responsable por actos cometidos por fuerzas bajo su mando y control efectivo como resultado de no haber ejercido un control apropiado sobre esas fuerzas. Esto se aplica cuando el jefe conoce o debería saber que los crímenes se han cometido o se van a cometer, y cuando hubiera adoptado todas las medidas necesarias y razonables para prevenir o reprimir la comisión o someter el asunto a investigación y enjuiciamiento. La responsabilidad de los superiores civiles es muy similar. Tales superiores son, sin embargo, responsables sólo de los crímenes de subordinados que el superior conocía o hizo caso omiso conscientemente de información que indicase claramente que los crímenes se habían cometido o iban a cometerse.

\section{B. Otros principios}

Manteniendo el principio de legalidad (nullum crimen sine lege), nadie será imputado penalmente de conformidad con el Estatuto por actos 
que no constituyan crímenes de acuerdo con éste al momento de que fueron cometidos. Se pide que la Corte interprete estrictamente las definiciones de los crímenes y no las haga extensivas por analogía, interpretando cualquier ambigüedad a favor de la persona objeto de la investigación, enjuiciamiento o condena. De esta manera se asegura que la discrecionalidad interpretativa de los magistrados se mantenga dentro de los límites establecidos por el Estatuto. Asimismo, una persona condenada por la CPI sólo puede ser castigada de acuerdo con sus términos (nulla poena sine lege).

El Estatuto no se aplica a conductas anteriores a su entrada en vigor (irretroactividad). En la eventualidad de un cambio en la ley antes de entrar en el juicio final de una causa, se aplicará la ley más favorable a la persona investigada, enjuiciada o condenada.

Los crímenes de la competencia de la CPI no prescribirán (imprescriptibilidad). Conforme a esta disposición, la Conferencia Diplomática reafirmó el ejemplo del Convenio sobre la No Prescripción de Crímenes de Guerra y Crímenes de Lesa Humanidad.

\section{Defensas o excepciones a la responsabilidad penal}

El Estatuto dispone de varias defensas, o circunstancias eximentes o de excepción de responsabilidad penal, que tendrán un impacto considerable sobre el ámbito de responsabilidad penal de conformidad con el propio instrumento. Como tales, serán importantes para los Estados que quieran disponer en su legislación de la posibilidad de conducir procesos en el nivel nacional. Las circunstancias eximentes o de exclusión de responsabilidad se dan cuando la persona:

- Padeciere una enfermedad o deficiencia mental...

- Estuviere en un estado de intoxicación... salvo que se haya intoxicado voluntariamente...

- Actuare razonablemente en defensa propia o de un tercero...

- Hubiere incurrido en una conducta ilícita... por coacción dimanante de una amenaza inminente de muerte...

En el juicio la Corte podrá tener en cuenta una circunstancia eximente de responsabilidad penal distinta de las indicadas, siempre que dicha circunstancia se desprenda del derecho aplicable de conformidad con el propio Estatuto. El procedimiento para el examen de una eximente de 
este tipo se establecerá en las Reglas de Procedimiento y Prueba. Un error de hecho o de derecho eximirá de responsabilidad penal sólo si hace desaparecer el elemento de intencionalidad requerido.

Igualmente, una persona no es relevada de responsabilidad penal por el hecho de que el crimen fuera cometido bajo órdenes de un gobierno o de un superior, sea militar o civil, a menos que estuviera obligado por ley a obedecer la orden, no supiera que la orden era ilícita o la orden no fuera manifiestamente ilícita. Cualquier orden de cometer genocidio o crímenes de lesa humanidad es manifiestamente ilícita.

\section{Límites a la competencia y su ejercicio}

La Corte tiene el deber de cerciorarse de ser competente sobre las causas que le sean sometidas. Al hacerse parte, los Estados reconocen la competencia de la Corte, sobre todo los crímenes de su competencia (sujeto a las disposiciones transitorias relativas a crímenes de guerra y la aplicabilidad limitada de crímenes recientemente adicionados conforme a los procedimientos de enmienda). No obstante, una constatación de competencia requiere más que la mera presunción de la misma, esto es, las condiciones previas para el ejercicio de la competencia de la Corte deben también cumplirse.

Éstas son características claves de dicha jurisdicción, y son el resultado de un compromiso cuidadoso en el que los mecanismos de activación, los temas materia de competencia, los procedimientos de admisibilidad y el esquema de cooperación confluyen para asegurar la legitimidad y eficacia de la CPI respetando la soberanía de los Estados. El territorio y la nacionalidad son los dos motivos más firmemente asentados en el derecho penal. Al vincular el ejercicio de competencia de la Corte con estas circunstancias, el Estatuto, en efecto, caracteriza a la Corte como una extensión de la competencia penal nacional de sus Estados partes. ${ }^{56}$

La capacidad de la Corte de ejercer su jurisdicción cuando el Estado en cuyo territorio ocurrió el crimen o el Estado de nacionalidad del acusado es parte (o ha consentido en forma ad hoc) encierra la posibilidad de que la Corte pueda en alguna ocasión ser capaz de ejercer competencia

56 Hubo mucho apoyo en la Conferencia Diplomática para un régimen más amplio en el cual la participación del Estado de nacionalidad de la víctima o el Estado de custodia pudiera ser suficiente para que la Corte ejerza su competencia. El Estatuto toma un enfoque más cauto, enfatizando la conexión de la Corte con la competencia de los Estados partes, y de ese modo incrementando su legitimidad y autoridad. 
sobre los nacionales de Estados no partes. Ahora bien, es fundamental para la concepción del Estatuto de que son los individuos, en su capacidad como individuos, quienes serán sancionados por crímenes dentro del imperio de la CPI. Esta idea es el núcleo del derecho internacional penal, la cual busca diferenciar al que participa en actos ultrajantes de la colectividad a la que reclama representar. En otros términos, es esta la focalización en la responsabilidad individual la que permite al derecho internacional penal contribuir a la reconciliación de comunidades.

Los otros límites sobre la admisibilidad y la competencia, incluyendo a aquellos que conducen al aplazamiento de una investigación cuando un Estado está llevando a cabo un proceso relativo a la misma causa, continuarán estando disponibles aun para Estados que no son partes.

Una investigación también debe "activarse" de conformidad con el Estatuto, y la causa constatarse admisible, es decir, que los Estados deben o haber cedido la causa a la Corte voluntariamente o estar de otra manera inactivos o con falta de disposición o realmente incapaces de proceder.

\section{Admisibilidad}

Además de los límites del régimen de competencia de la Corte, un límite fundamental para la capacidad de la Corte de ejercer sus facultades es el principio de complementariedad. Si concebimos al tribunal como una extensión de la jurisdicción penal nacional de los Estados, las disposiciones de admisibilidad dejan en claro que la CPI no es una extensión de los sistemas de administración nacional de justicia penal de esos Estados, esto es, de ninguna manera las sustituye, sino que es complementaria actuando cuando son incapaces o les falta disponibilidad para hacerlo por sí mismos. La responsabilidad primaria de investigar y enjuiciar los crímenes de la competencia de la Corte continuará estando en manos de los Estados, y sólo cuando éstos no procedan o estén inactivos o prefieran que la Corte actúe, será posible que la CPI pueda determinar admisible un asunto. La complementariedad va al centro del régimen del Estatuto, al concebir una Corte capaz de fortalecer y complementar, no reemplazar las investigaciones y enjuiciamientos nacionales.

Asimismo, establece las condiciones bajo las cuales un asunto podría ser inadmisible ante la Corte, y dispone las circunstancias procesales en las cuales dará la constatación sobre la admisibilidad y competencia. Se le pueden presentar impugnaciones a la admisibilidad o competencia por un 
acusado o un sospechoso con orden de detención o de comparecencia, por cualquier Estado que tenga algún tipo de injerencia en el asunto. El fiscal también puede hacer una constatación sobre admisibilidad o competencia. Cuando un Estado hace una impugnación, el fiscal debe suspender la investigación en espera de una decisión, aunque pueda pedir a la autoridad dar los pasos para evitar o prevenir que las personas huyan. Los asuntos se considerarán inadmisibles en cuatro circunstancias, y son cuando:

a) El asunto sea objeto de una investigación o enjuiciamiento en el Estado que tiene jurisdicción sobre él salvo que éste no esté dispuesto a llevar a cabo la investigación o el enjuiciamiento o no pueda realmente hacerlo;

b) El asunto haya sido objeto de investigación por el Estado que tenga jurisdicción sobre él y éste haya decidido no incoar acción penal contra la persona de que se trate, salvo que la decisión haya obedecido a que no esté dispuesto a llevar a cabo el enjuiciamiento o no pueda realmente hacerlo;

c) La persona de que se trate haya ya sido enjuiciada por la conducta a que se refiere la denuncia, y la Corte no pueda incoar el juicio con arreglo a lo dispuesto en el párrafo 3 del artículo 20;

d) El asunto no sea de gravedad suficiente para justificar la adopción de otras medidas por la Corte.

Para Estados partes que deseen que sus autoridades nacionales ejerzan competencia sobre crímenes presuntamente cometidos por sus nacionales o en su territorio, en vez de la CPI, las disposiciones de admisibilidad pueden tener implicaciones significativas para la implementación de la legislación nacional.

\section{Mecanismos de activación y aplazamiento}

El Estatuto dispone tres medios por los cuales la Corte puede iniciar juicios:

\section{A. Estados partes}

Los Estados partes tienen facultad de remitir a la Corte situaciones en las que un crimen o crímenes de su competencia parecieran haberse cometido. Permitiendo la remisión de "situaciones" en vez de "causas" deja al fiscal que decida sobre la base de su investigación a qué individuos acusar formalmente. 


\section{B. El Consejo de Seguridad}

La facultad del Consejo de Seguridad de remitirle situaciones a la CPI le brinda a ésta la posibilidad de constituirse en un foro para juicios relativos a asuntos que amenazan la paz y seguridad internacionales. La prerrogativa del Consejo deriva finalmente de la Carta de Naciones Unidas (capítulo VII), no del Estatuto de Roma, y de este modo estará disponible aun con respecto a Estados que no son partes de este último. Una vez que una investigación o enjuiciamiento está en curso, y dejando de lado cómo fue iniciado, la Corte está obligada a suspenderlo hasta por doce meses si el Consejo de Seguridad, en una resolución apegada a la Carta de la ONU, así lo solicita; tal petición puede ser renovada por el Consejo en las mismas condiciones.

\section{El fiscal}

La Corte puede también ejercer su competencia cuando el fiscal inicie una investigación motu proprio. Esta facultad es importante, porque asegura que la Corte pueda funcionar si otras circunstancias evitan que los Estados o el Consejo de Seguridad le remitan situaciones. ${ }^{57}$ El fiscal puede recibir información de cualquier fuente confiable, y debe analizar su veracidad. Una vez que concluya que hay una base razonable para abrir una investigación, debe hacer un pedido a la Sala de Cuestiones Preliminares de tres magistrados de autorización para investigar, la cual, de estar sustentada, será aprobada, sin perjuicio de constataciones posteriores que pueda hacer sobre competencia o admisibilidad.

Cuando un Estado ha remitido una situación o el fiscal ha iniciado una investigación motu proprio, éste está obligado a notificar a todos los Estados partes, así como a aquellos Estados (aun si no son partes) que "normalmente tendrían jurisdicción" sobre los crímenes de que se trate. Esto incluye al menos a los Estados de territorio, de custodia o de nacionalidad del acusado o de la víctima. Si al cabo de un mes de la recepción de la notificación, alguno de los Estados informa a la Corte que está investigando o ha investigado la materia, a pedido de este Estado el fiscal aplazará su propia investigación. Esta obligación de aplazar no es ilimita-

57 Viendo a la luz de los pocos y cuidadosamente circunscritos crímenes de la competencia de la Corte, los procedimientos de admisibilidad, los requisitos jurisdiccionales, y sobre todo, las garantías procesales que delimitan las acciones del fiscal, quedó claro que esta facultad promueve un interjuego efectivo y balanceado entre las jurisdicciones nacional e internacional. 
da. La Sala de Cuestiones Preliminares puede autorizar al fiscal a investigar sobre la base de la falta de disposición o incapacidad real del Estado de llevar a cabo el enjuiciamiento, pese a su pedido de aplazamiento. El fiscal también puede solicitar autoridad a la Sala a continuar con la investigación para preservar pruebas en caso de haber una oportunidad única o el riesgo de perderse posteriormente. Finalmente, el deber de aplazar, así como el de notificar, se aplica igualmente a pedidos de Estados que no son partes.

\section{Procedimientos de la Corte}

Las disposiciones del Estatuto para la investigación forman un sistema de normas estrechamente integrado, haciendo que los procedimientos del tribunal se ajusten a las más avanzadas normas del debido proceso y garantizando los intereses de la defensa; amén de ser sensibles a las preocupaciones de los Estados y de proteger la capacidad de la CPI de desempeñar sus funciones. Es a través de estas normas como el Estatuto asegurará la integridad y autoridad del tribunal en el largo plazo. Recordemos que las definiciones, los principios generales y las normas procesales fueron la mayor fuente de críticas para el Tribunal de Nüremberg. Así, basándose en lo desarrollado en la normativa procesal internacional y en el progreso realizado por los tribunales para la ex yugoslavia y Ruanda, la CPI se propone asegurar que la legitimidad del procedimiento penal internacional jamás sea puesta en duda.

Las disposiciones estatutarias, que serán vistas muy panorámicamente a continuación, serán perfeccionadas y complementadas por las Reglas de Procedimiento y Prueba. Éstas serán preparadas en un proyecto por la Comisión Preparatoria y luego examinadas y adoptadas, según proceda, por una mayoría de dos tercios de la Asamblea de Estados partes. Cualquier Estado puede hacer enmiendas a las Reglas, así como el fiscal y una mayoría absoluta de magistrados; las enmiendas entrarán también en vigor bajo la aprobación de una mayoría de dos tercios de la Asamblea. Las Reglas serán compatibles con el Estatuto. Los procedimientos de la Corte son básicamente tres: la investigación, el juicio y la apelación.

\section{A. La investigación}

Sea como fuere que se iniciaron los procesos, el fiscal evaluará la información recibida e iniciará una investigación a menos que determine 
que no hay un fundamento razonable para abrir proceso. Al tomar esta decisión, tendrá en cuenta las probables constataciones de competencia y admisibilidad de la Corte y el interés de la justicia. Sirve no sólo a convicciones fijas, sino a que se establezca la verdad y se haga justicia; por eso tiene el deber de investigar circunstancias eximentes o incriminatorias por igual, con respecto a los intereses y situaciones personales de las víctimas y los testigos (incluyendo la edad y el género) tomando en cuenta la naturaleza del crimen (en particular si involucran violencia sexual o de género) y respecto a los derechos que confiere el Estatuto a las personas. Sus facultades para conducir investigaciones incluyen la prerrogativa de reunir y examinar pruebas, para hacer comparecer e interrogar a varias personas, asegurar la confidencialidad, la protección de las personas y la preservación de las pruebas, y así sucesivamente; asimismo, para solicitar la cooperación de los Estados o llegar a acuerdos para facilitarla, permitiendo así la colaboración voluntaria entre fiscal y Estados.

Ello es importante porque, a falta de este binomio, el fiscal no tiene poderes coercitivos, y debe recurrir a los procedimientos de cooperación del Estatuto. Una excepción a esta situación es que el fiscal puede conducir investigaciones en el territorio de un Estado, autorizado por la Sala de Cuestiones Preliminares, cuando un Estado parte es claramente incapaz de ejecutar una solicitud de cooperación debido a que no existe autoridad $\mathrm{u}$ órgano alguno de su sistema judicial competente para cumplir dicha solicitud de derechos en virtud del Estatuto:

- Derecho contra la autoincriminación

- Derecho a estar libre de coacción

- Derecho a estar libre de arresto o detención distinto a lo dispuesto por el Estatuto

- Derecho a ser informado antes del interrogatorio por funcionarios del Estado o de la Corte de que hay motivos para creer que ha cometido un crimen competencia de la Corte

- Derecho a guardar silencio

- Derecho a tener asistencia legal

- Derecho a tener abogado (gratuitamente de ser necesario)

- Derecho a ser interrogado en presencia de su abogado

- Derecho a solicitar libertad provisional

- Derecho a preparar la defensa y a ser procesado sin dilaciones indebidas 
- Derecho a un juicio justo e imparcial

- Derecho a estar presente durante el juicio

- Derecho de presunción de inocencia

- Derecho a declarar de palabra o por escrito en su defensa sin prestar juramento y a que no se invierta la carga de la prueba ni le sea impuesta la carga de presentar contrapruebas.

Estos derechos, y el derecho a estar informado de ellos, también se aplican cuando el interrogatorio es llevado a cabo por autoridades del Estado a solicitud de la CPI. La Sala de Cuestiones Preliminares adoptará las medidas necesarias para velar por la eficiencia e integridad de las actuaciones, permitiendo a la defensa participar, ordenando a un magistrado a observar y dar órdenes y recomendaciones o tomar otras medidas para reunir o preservar pruebas, amén de actuar por propia iniciativa para salvaguardar los derechos de la defensa y, en general, dictar órdenes o requisitorias para una investigación, preparación de una defensa, brindar la protección a las víctimas o testigos, o preservar pruebas, y buscar la cooperación estatal en la protección de bienes posibles de ser decomisados.

$\mathrm{El}$ fiscal debe convencer a la Corte de que hay motivos razonables para creer que la persona cometió un crimen y que la detención es necesaria para asegurar su presencia en el juicio, para evitar la obstrucción de la investigación o del proceso, o para impedir que la persona siga cometiendo ese crimen. Si lo adecuado es asegurar la comparecencia, puede dictar la orden de comparecencia en vez de la de detención y entrega. No se otorgará libertad provisional si los motivos de "necesidad" que fundamentaron la orden de detención se encuentran aún vigentes. La Sala puede revisar, modificar o revocar una decisión de libertad provisional, y también, liberar a una persona detenida a la luz de una demora inexcusable del fiscal.

La audiencia para la confirmación de cargos se realizará dentro de un plazo razonable después de la primera comparecencia. Dichas audiencias pueden sostenerse en ausencia del acusado sólo en circunstancias limitadas. La defensa tiene derecho a conocer las pruebas sobre las cuales se basará el fiscal en la audiencia, quien debe mostrar "motivos fundados" para creer que el acusado cometió cada cargo, pudiendo éste a su vez objetar, impugnar y presentar sus propias pruebas. La Sala puede luego someter al acusado a la Sala de Primera Instancia sobre cualquiera de los cargos confirmados. 


\section{B. El juicio}

Después de bastante debate en la Conferencia Diplomática no se dispusieron los juicios in absentia en el Estatuto; esto es, el acusado tiene el derecho de estar presente durante el juicio, excepto cuando perturbara continuamente el proceso. La Sala de Primera Instancia tiene la obligación de ver que el juicio sea justo y expedito y conducido con pleno respeto a los derechos del acusado y con la debida protección a las víctimas y testigos; además, podrá solicitar la comparecencia y testimonio de testigos y la presentación de documentos, proteger la confidencialidad de la información y brindar protección al acusado, los testigos y las víctimas, y dirimir cualesquiera otras cuestiones pertinentes. Con algunas limitadas excepciones que permiten sesiones cerradas para proteger víctimas, testigos o información confidencial o sensible, los juicios se sostendrán públicamente.

El Estatuto observa un compromiso entre los enfoques que toman diferentes sistemas legales del mundo respecto a la declaración de culpabilidad. La Corte tiene el deber de asegurar que el acusado entienda las consecuencias de una admisión de culpabilidad, que hace voluntariamente tras suficiente consulta con el abogado defensor y corroborada por los hechos de la causa. La Corte puede convencerse de esto o, si no lo constata, puede ordenar que prosiga el juicio con arreglo al procedimiento ordinario. En respuesta al fenómeno de "pedido de negociación", el tribunal no está comprometido con ninguna discusión entre el fiscal y la defensa respecto a la modificación de los cargos, la declaración de culpabilidad o la condena a ser impuesta.

La CPI tiene una obligación general de "adoptar las medidas adecuadas para proteger la seguridad, el bienestar físico y psicológico, la dignidad y la vida privada de las víctimas y los testigos", tomando en cuenta factores tales como la edad, el género y el tipo. Asimismo, las opiniones y observaciones de las víctimas cuyos personales intereses se vieran afectados serán presentadas y tenidas en cuenta en las fases del juicio que se consideren pertinentes sujeto a los derechos del acusado.

El Estatuto establece un marco básico relativo a las pruebas. El testimonio de un testigo en el juicio deberá darse generalmente en persona. La Corte puede pedir la presentación de cualquier prueba que juzgue necesaria para la determinación de la verdad y puede, de acuerdo con criterios señalados en las Reglas, decidir sobre la pertinencia o admisibilidad de 
cualquier prueba, teniendo en cuenta, entre otras cuestiones, el valor probatorio y cualquier perjuicio que pueda suponer para un juicio. De modo importante, las pruebas obtenidas como resultado de una violación del Estatuto o de las normas de derechos humanos internacionalmente reconocidas serán inadmisibles si la violación suscita serias dudas sobre la fiabilidad de las pruebas o si su admisión atentara "contra la integridad del juicio o redunde en grave desmedro de él".

El Estatuto establece seis delitos contra el sistema de administración de justicia. Éstos incluyen, cuando se cometieron intencionalmente:

- Dar falso testimonio

- Presentar pruebas que se sabe son falsas o falsificadas

- Interferir con un testigo o con una prueba

- Interferir con un funcionario de la Corte

- Solicitar o aceptar un soborno en calidad de funcionario de la Corte.

Los procedimientos relativos a estos delitos, sancionables con multa o pena de reclusión no mayor de cinco años, serán establecidos en las Reglas. Aun cuando la CPI puede proceder con respecto a estas conductas, puede solicitar también a un Estado parte que lo haga; consecuentemente, el Estatuto obliga a los Estados a extender sus leyes penales de acuerdo con ello.

Un Estado tiene el derecho de intervenir cuando siente que la divulgación de información requerida conforme al Estatuto puede afectar los intereses de su seguridad. El Estado, el fiscal, la defensa y las Salas pertinentes deben adoptar todos los pasos necesarios para resolver la cuestión por medio de la cooperación con medidas tales como la modificación de la solicitud, la obtención de la información de una fuente distinta o en una forma diferente (como por ejemplo resúmenes), o acordando condiciones tales como limitaciones en la divulgación, utilizando procedimientos a puerta cerrada o ex parte u otras medidas. Si aun realizado esto el Estado continúa en su posición, se notificará a la Corte, la que si encuentra que la prueba es necesaria para establecer la culpabilidad o la inocencia del acusado puede, como último recurso, determinar que el Estado no está cumpliendo con sus obligaciones de conformidad con el Estatuto, y puede remitir la materia a la Asamblea de Estados partes, o, si procede, al Consejo de Seguridad. 
Por su parte, los magistrados intentarán llegar a decisiones de condena o absolución unánimemente, a falta de lo cual decidirá la mayoría. Las opiniones de la mayoría y la minoría - incluyendo, de ser posible, la valiosa "opinión disidente" - aparecerán en la evaluación que será leída (probablemente en forma resumida) en sesión pública.

La Corte Penal Internacional establecerá principios aplicables a la reparación, incluidas la restitución, la indemnización y la rehabilitación que ha de otorgarse a las víctimas o a sus causahabientes. A pedido de la víctima o (excepcionalmente) por su propia iniciativa, la Corte puede determinar el alcance y la extensión del daño, pérdida o lesión de las víctimas, pudiendo dar órdenes de reparación directamente contra una persona condenada, o puede ordenar un pago de un fondo fiduciario.

\section{La apelación}

Las apelaciones a las decisiones de la Corte pueden ser hechas por el fiscal (motu proprio o a favor del condenado) o por la persona condenada por motivos de vicio de procedimiento, error de hecho o de derecho, así, en razón de una desproporción entre el crimen y la condena. La persona condenada puede también apelar por cualquier otro motivo "que afecte la justicia o la regularidad del proceso o del fallo". Una persona condenada se mantendrá en custodia en espera de la apelación a menos que la Corte ordene lo contrario. Al esperar la apelación de una absolución, la persona absuelta será liberada excepto bajo circunstancias excepcionales tomando en cuenta el riesgo de fuga, la gravedad del delito y las probabilidades de que se dé lugar a la apelación.

Otras decisiones pueden ser apeladas antes de la conclusión del juicio, incluyendo aquellas sobre admisibilidad y competencia, sobre libertad provisional, sobre iniciativas de la Sala de Cuestiones Preliminares o sobre alguna cuestión "que afecte de forma significativa a la justicia y a la prontitud con que se sustancia el proceso o a su resultado". Las órdenes de reparación pueden ser apeladas por un representante de las víctimas, así como por el condenado o por un propietario de buena fe de bienes afectados por una orden de decomiso.

De encontrarse alguna injusticia en la decisión o sentencia, o un error que les afectó efectivamente, la Sala de Apelaciones puede revertir o enmendar la decisión o sentencia o puede ordenar un nuevo juicio. $\mathrm{O}$ bien, puede variar una sentencia desproporcionada. Si se cerciora de que ha sa- 
lido a la luz una nueva prueba importante, o que se ha descubierto que una prueba decisiva es falsa, o que uno o más de los magistrados estuvieron involucrados en una falta grave en su función, puede remediar el hecho volviendo a convocar a la Sala de Primera Instancia o constituyendo una nueva o reteniendo competencia para determinar si debe revisarse la sentencia definitiva condenatoria o la pena.

El que haya sido ilegalmente detenido o recluido tendrá el derecho efectivo a ser indemnizado, así también quien hubiera sido condenado por un error judicial.

\section{Fallos condenatorios y su ejecución}

Un condenado por la Corte sólo puede ser sancionado conforme a las penas contenidas en el Estatuto (nulla poena sine lege). Después de registrarse una condena la Sala de Primera Instancia fijará la pena y puede (por su propia iniciativa) o debe (a pedido del acusado o del fiscal) convocar una audiencia especial para este propósito. La pena será impuesta en audiencia pública y, de ser posible, en presencia del acusado.

Las penas disponibles para la CPI son:

- Reclusión por un número determinado de años que no exceda de treinta;

- Reclusión a perpetuidad cuando lo justifiquen "la extrema gravedad del crimen o las circunstancias personales del condenado";

- Pago de una multa y/o un decomiso del producto, los bienes y los haberes procedentes directa o indirectamente de dicho crimen.

La pena de muerte no está incluida entre las penas posibles. Sin embargo, el Estatuto declara expresamente que no afecta la aplicación por los Estados partes de penas prescritas por su derecho interno. Esto significa que la no inclusión de la pena de muerte no tiene consecuencias para fallos dictados de conformidad con el derecho interno después de juicios nacionales ante tribunales de los Estados partes.

La parte X ("De la ejecución de la pena", artículos del 103 al 111) preceptúa el régimen por el cual los fallos dados por la CPI serán ejecutados, y refleja la medida en que interactuarán la Corte y los Estados partes en promover el estado de derecho internacional (penal). Los artículos de ejecución se dividen entre los que se aplicarán a todos los Estados partes y los que no lo harán. 
Las disposiciones relativas a fallos condenatorios de reclusión se aplican sólo a los Estados que expresen su disposición de que los condenados por la Corte cumplan sus condenas en su territorio. Al designar el Estado de Ejecución de entre aquellos que están dispuestos a asumir condenados, la CPI considerará factores tales como distribución equitativa entre Estados partes, la aplicación de normas internacionales ampliamente aceptadas y opiniones del condenado. Aunque sujeta a posibles condiciones impuestas por el Estado ejecutor, la condena establecida por la Corte es vinculante sobre Estados partes, y no puede modificarse, y sólo ella puede decidir cualquier solicitud de apelación o revisión. La ejecución está sujeta a su supervisión, y aunque gobernada por el derecho interno, debe ser compatible con las normas de tratados internacionales ampliamente aceptados respecto al trato de prisioneros.

La CPI tiene el derecho de decidir sobre cualquier reducción de pena y realizar revisiones para este propósito después de que se hayan cumplido dos tercios de la condena o de veinticinco años en caso de reclusión perpetua. Los Estados ejecutores cooperarán con la Corte en pedir la entrega de un prisionero a un tercer Estado luego de una fuga.

Por cuanto es a la ejecución de multas y decomisos ordenados por la CPI, los Estados partes están obligados a hacerlos efectivos o a tomar medidas para la recuperación de un valor equivalente cuando el decomiso no es posible, y a hacer la transferencia apropiada a la Corte, sin perjuicio de los derechos de buena fe de terceras partes. La Asamblea de Estados partes establecerá un fondo fiduciario para víctimas o sus familiares, y la Corte tendrá la capacidad de ordenar que se pague a este fondo el dinero u otra propiedad derivada de multas o decomisos.

\section{Financiación}

Las cuestiones financieras se regirán por el Estatuto y por las reglas y reglamentaciones financieras a ser proyectadas por la Comisión Preparatoria y luego adoptadas por la Asamblea de Estados partes. Los fondos de la CPI serán proporcionados por las contribuciones prorrateadas de los miembros, y de los fondos suministrados por las Naciones Unidas con la aprobación de la Asamblea General (particularmente para gastos relacionados con las remisiones del Consejo de Seguridad).

Los prorrateos se harán basados en los mismos principios del presupuesto ordinario de la ONU. También se contemplan contribuciones vo- 
luntarias compatibles con las normas adoptadas por la Asamblea (con el propósito de garantizar la independencia de la Corte).

Se prevé que un Estado parte que esté en mora en el pago de sus contribuciones financieras a los gastos del tribunal no tendrá voto en la Asamblea o en la mesa si la suma adeudada es igual o superior al total de las contribuciones adeudadas por los dos años anteriores completos (salvo que en el retraso haya circunstancias ajenas a su voluntad).

Las regulaciones de personal propuestas por el secretario en acuerdo con la presidencia y el fiscal, que establecerán los términos y condiciones aplicables al personal de la Corte, están sujetas a la aprobación de la Asamblea de Estados partes, la cual también dará las directrices para el uso de personal proporcionado gratuitamente por Estados partes, organizaciones intergubernamentales u organizaciones no gubernamentales, igualmente, fijará los sueldos, estipendios y dietas de los magistrados, el fiscal, los fiscales adjuntos, el secretario y el secretario adjunto.

\section{Enmiendas, denuncias y reservas. Cláusulas finales}

La Corte dirimirá las controversias relativas a las funciones judiciales, y las que surjan sobre la aplicación o interpretación del Estatuto que no se resuelvan entre las partes en el plazo de tres meses serán remitidas a la Asamblea, la cual puede tratar de resolver la diferencia o hacer recomendaciones, incluida su remisión a la Corte Internacional de Justicia.

Los Estados pueden proponer enmiendas sólo después de siete años de entrada en vigor (incluso entonces, adoptar una enmienda y que entre en vigor será difícil). Una enmienda sobre la cual no se puede llegar a consenso requiere de una mayoría de dos tercios de todos los Estados partes.

Después de la adopción, la enmienda entrará en vigor de dos modos posibles:

- Las enmiendas relativas a un artículo distinto a aquellos que establecen y definen crímenes de competencia de la Corte entrarán en vigor para todos los Estados un año después de la ratificación de la enmienda por siete octavos de ellos (un Estado que no la haya aceptado tiene el derecho a denunciar el Estatuto con efecto inmediato).

- Una enmienda a los artículos que establecen y definen los crímenes de competencia de la Corte entrará en vigor un año después de la ratificación sólo para aquellos Estados que la acepten. Por tan- 
to, la CPI no ejercerá competencia sobre un crimen comprendido en la enmienda si la conducta se ha cometido en el territorio o por nacionales de un Estado que no la ha aceptado.

- Un tercer procedimiento de enmienda se aplica a disposiciones "de carácter exclusivamente institucional", que se pueden proponer en cualquier momento (y sólo siete años después de la entrada en vigor). Si se adoptan por una mayoría de dos tercios, entran en vigor para todos los Estados partes seis meses más tarde.

Siete años después de la entrada en vigor, el secretario general de las Naciones Unidas convocará a una conferencia de revisión para examinar las enmiendas al Estatuto. La tarea principal de la primera conferencia de revisión ya está dada: propuestas preparadas por la Comisión Preparatoria sobre el crimen de agresión, y los crímenes de terrorismo y tráfico de drogas, con una opinión de llegar a definiciones aceptables y mecanismos jurisdiccionales para su inclusión en el Estatuto.

Un Estado parte está habilitado para denunciar el Estatuto haciéndose efectivo un año después de notificarlo al secretario general de la ONU. La denuncia no afectará las obligaciones (incluidas las financieras) que le incumbieran mientras era parte, así como el deber de cooperar con la Corte con respecto a investigaciones o enjuiciamientos que se hayan iniciado antes de que surta efecto, así como cualquier otra cuestión examinada por el tribunal antes de esa fecha.

Respecto a las reservas, según el artículo 120, no se admiten reservas al Estatuto. Sin embargo, el artículo 124 dispone que un Estado puede, al hacerse parte del instrumento, declarar que por siete años después de entrar éste en vigor no aceptará la competencia de la Corte sobre crímenes de guerra con respecto a sus nacionales o a actos cometidos en su territorio. Dicha declaración limitará la competencia de la CPI, a menos que se la retire. Esta disposición transitoria especial fue introducida como una concesión de último minuto en la conferencia diplomática: en nuestra opinión, ejercer esta opción atraerá mucha crítica, y se espera que pocos Estados o ninguno hagan uso de ella.

\section{Algunas consideraciones sobre la relación de la CPI} con el derecho interno de los Estados partes. El caso de México

Este tema, el de la relación de la CPI con el derecho interno de los Estados partes, tiene un impacto inusitado en la comprensión disciplinaria 
del derecho internacional penal actual y reviste una importancia nodal para el investigador de los procesos penales en tratándose de crímenes y delitos transfronterizos de las relaciones internacionales contemporáneas. $\mathrm{Al}$ respecto, hemos de aclarar que por razones de que el presente artículo ha rebasado, por su extensión, los límites de espacio que originalmente le fueron asignados, no nos será posible abordarlo. Empero, sólo enunciaremos algunos puntos básicos de su contenido, junto con ciertas apreciaciones sobre las disposiciones y criterios del Estatuto que, en principio, parecen contraponerse con algunos de los preceptos constitucionales y legales del sistema jurídico mexicano, mismos que deben ser detenidamente considerados por el hecho de que constituyeron el argumento central esgrimido por el Ejecutivo Federal para posponer la firma del instrumento por más de dos años, y que pesarán sobremanera en la opinión de las autoridades facultadas para ratificarlo y convalidarlo en el futuro.

En cuanto al primer punto, la relación CPI-derecho interno, involucrará dos áreas principales de complementariedad y cooperación, o investigación y enjuiciamiento por las administraciones nacionales de justicia de crímenes de la competencia de la Corte, y la cooperación de los Estados en el ejercicio de la competencia de la CPI. Los Estados que están examinando la ratificación - como México a partir del 7 de septiembre de 2000 - querrán conocer, por supuesto, su posición respecto al tribunal. Primero, ¿cómo deben conducirse los procesos en el ámbito nacional para satisfacer los requisitos de "complementariedad" del Estatuto? Esto es, ¿cómo debe conducir un Estado sus investigaciones y enjuiciamientos de sus autoridades y que no sea la CPI la que ejerza competencia sobre los hechos en cuestión? En segundo lugar, ¿cómo se cumplirá con el deber de cooperar en virtud del Estatuto? Éstas son cuestiones relacionadas, ya que un fracaso en ejercer competencia puede conducir a que la CPI la adquiera y por tanto desencadenar la obligación a cooperar. Dependiendo de las disposiciones constitucionales en un Estado dado, cada uno puede requerir de una revisión y posibles cambios en su derecho interno.

La medida en que un Estado dado tendrá que hacer cambios a su legislación nacional para equipararla con el sistema legal de la CPI dependerá de la estructura constitucional y legal de ese Estado. Algunos podrán ratificar el Estatuto sin cambios en su derecho interno, cuando las obligaciones del Estado automáticamente se hacen parte de esa legislación. Otros necesitarán un orden legal muy elemental, declarando la ley sustantiva y los procedimientos de cooperación del Estatuto como parte del derecho 
endógeno, y haciendo caso omiso de cualquier ley con la que pueda haber incompatibilidad. En la mayoría de casos, empero, la implementación no es tan simple, y un Estado debe hacer cambios específicos para adecuar el derecho interno con sus obligaciones internacionales. En tales casos, los Estados querrán conducir una revisión de la legislación nacional para identificar los cambios que conllevan sus obligaciones de conformidad con el Estatuto. Ciertamente, la implementación de una legislación nacional efectiva se preparará tanto para enjuiciamientos nacionales de genocidio, crímenes de lesa humanidad y crímenes de guerra, como para la cooperación con la Corte, el modo previsto en los términos del instrumento.

En cuanto a la posición de México frente a la CPI, mencionaremos que nuestro país se abstuvo en la votación para la aprobación del Estatuto que la estableció en la Conferencia Diplomática de Roma, realizada del 15 de junio al 17 de julio de 1998, con 120 votos a favor, 7 en contra ${ }^{58}$ y 21 abstenciones, aunque se limitó a firmar el acta final de la Conferencia, entre otras razones — las oficiales, por supuesto - por la necesidad de someter el texto al análisis por parte de las dependencias involucradas del Ejecutivo Federal. Consecuentemente, la Secretaría de Relaciones Exteriores convocó a una comisión intersecretarial (SEGOB, PGR, SEDENA), para analizar la compatibilidad el Estatuto de la CPI con la Constitución Política y leyes reglamentarias, y definir la posición que asumirá el país con respecto a su firma - ya protocolizada después de dos años- y ratificación.

Es un hecho que la dificultad de conciliar las diversas posiciones sobre los principales aspectos del Estatuto, así como la presión de la opinión pública internacional para apresurar su adopción, impidió llegar a un acuerdo general sobre algunos temas nodales del mismo, lo que imposibilitó su aprobación por consenso. Esta situación, junto con el notorio desconocimiento por los funcionarios enviados tanto del contenido profundo y técnico del Estatuto y de sus alcances como del derecho internacional general y penal, además de que seis de las disposiciones del texto parecen contradecir —más en la forma que en el fondo- ocho disposiciones constitucionales, propiciaron que México retrasara notoriamente su firma, aun habiendo aceptado convencionalmente el acta final. Las disposiciones en aparente contravención son, grosso modo, las siguientes:

58 Los países que votaron en contra fueron: Estados Unidos, Israel, China, India, Turquía, Filipinas y Sri Lanka. 
- Mientras que el Estatuto permite que una persona pueda ser juzgada dos veces por el mismo delito (principio de la cosa juzgada, non bis in idem) en México esto no es posible conforme al artículo 23 constitucional.

- Se afirma que el Estatuto viola las garantías de que un mexicano deba ser juzgado en México por delitos cometidos en México, amén de que no está prevista la entrega de un nacional a un tribunal extranjero para su enjuiciamiento, ello conforme se desprende de los artículos constitucionales 15, 16, 17, 18, 19 y 21.

- El Estatuto permite — sólo bajo casos excepcionales - juicios en ausencia (in absentia), los cuales no están previstos o permitidos en la legislación nacional, como se desprende de lo preceptuado por el artículo 17 constitucional.

- El Estatuto admite la capacidad de la Corte para realizar investigación penal en México o por otros Estados parte, lo cual está constitucionalmente reservado al Ministerio Público mexicano, esto es, se contraviene el artículo 19 de la ley fundamental.

- El Estatuto de Roma establece expresamente la imprescriptibilidad de los delitos competencia de la Corte, lo cual no está previsto en la legislación nacional, contraviniéndose lo señalado en el artículo 14 constitucional.

- En la parte relativa a los fallos condenatorios y su ejecución, el Estatuto prevé la cadena perpetua, pena que no está contemplada en el marco legislativo mexicano, contraviniéndose también el artículo 14 de la Constitución Política.

- Otros argumentos y objeciones que han manifestado representantes mexicanos en relación con este asunto de la compatibilidad CPI-legislación nacional —en los que no entraremos en detalleson los siguientes: 59

- Excesiva vinculación entre la CPI y el Consejo de Seguridad de las Naciones Unidas.

- Escasa interconexión de la CPI con la Asamblea General y —menor aún- con la Corte Internacional de Justicia de las Naciones Unidas.

59 Tomado de la ponencia presenta por el embajador Sergio González Gálvez, delegado de México ante la Conferencia Diplomática de Roma, de junio-julio de 1998, que con el título "México y la Corte Penal Internacional”, presentó en el Seminario de Justicia Penal Internacional, organizado por la Universidad Iberoamericana, campus Santa Fe, del 24 al 28 de febrero de 2000. 
- La no inclusión de las armas de destrucción masiva como crimen de guerra, lo cual se considera incompatible con las tesis tradicionales sostenidas por México y por la inmensa mayoría de los países miembros de la ONU.

- Ampliación de última hora - lo cual no fue así- de la competencia de la CPI en relación con otros crímenes internacionales, como tráfico ilegal de drogas y terrorismo.

Limitantes excesivas al alcance del capítulo relativo a los crímenes de guerra.

El hecho de que no se permiten reservas al Estatuto requeriría hacer una declaración interpretativa al momento de la firma y/o ratificación, o bien plantearse enmiendas a la Constitución en vigor.

El artículo 24 del Estatuto establece la improcedencia del cargo oficial ("el cargo oficial de una persona no obstará para que la CPI ejerza su competencia sobre ella"), lo que podría ser inconsistente con los artículos 108 al 111 de la Constitución federal, contraponiéndose en particular con la inmunidad procesal en materia penal, consagrada para cierto nivel de servidores públicos de alta jerarquía.

Resulta todavía controvertido el artículo 54 bis del Estatuto, que establece las funciones y atribuciones del Fiscal con respecto a las investigaciones, las cuales podrá realizar en el territorio de un Estado.

Éstas y otras incompatibilidades con nuestra Constitución o leyes secundarias pudieron al menos en algunos casos haberse superado con sendas reservas, pero el asunto se complicó — recordar que éstas son opiniones oficiales que no necesariamente compartimos- cuando a último momento, sin consultas previas, el funcionario que presidió la Comisión Plenaria de la Conferencia de Roma (a quien directamente se responsabiliza de romper la negociación y presentar un texto que sólo satisfacía a un pequeño grupo de países) eliminó, sin más, la cláusula que permitía reservas a la Convención.

Considerando de antemano que la posición de México no es estática y que hasta la fecha funciona con regularidad un grupo intersecretarial del gobierno federal que estudia la manera más adecuada para resolver - lo más expeditamente posible - estas faltas de correspondencia legal, es de esperarse que nuestro país participe activa y constructivamente en el proceso que ya se ha iniciado, en el marco de la Asamblea General de las 
Naciones Unidas, para formular los reglamentos de la Corte y tipificar los elementos del crimen.

\section{CONCLUSIONES}

Al llegar a este momento nos asaltan sentimientos contradictorios de satisfacción y de duda razonada que, por un lado, nos invitan a continuar en la atrayente expectativa de una investigación que apenas comienza y, por el otro, nos devuelven al principio, al replanteamiento, a la circunstancia propia de todo estudioso de lo social cuando sólo tiene ante sí un conocimiento, una idea y sólo hojas de papel en blanco; por ello, a estas alturas del recorrido sólo podemos invitar al lector a la reflexión compartida y recreativa sobre el tema que ya comenzó a ocuparnos: el del derecho internacional penal y la justicia penal internacional en el tercer milenio, en espera de haber cumplido el objetivo de realizar un balance analítico-crítico de su desempeño frente a las transformaciones y patología de las relaciones internacionales contemporáneas.

Como lo hemos afirmado en anteriores contribuciones: porque el paso del tiempo es inexorable, es arriesgado plantear conclusiones como aseveraciones absolutas y terminales, pues más bien se trata de simples reflexiones con bases científicas, pero asentadas en la relatividad del tiempo y el espacio. Concluir algo implica para el que concluye, una gran responsabilidad consigo mismo y con el lector: la esencial validez temporal y relativa de las conclusiones en el amplio espectro de las ciencias jurídicas y sociales nos hace dudar de su carácter definitivo, mas no de su papel definitorio. Por ello, podría resultar apriorístico expresar criterios conclusivos sobre fenómenos tan dinámicos, complejos y multidimensionales como lo son las relaciones internacionales y el derecho internacional general y penal. Aunque sí debe resaltarse que los planteamientos y las estructuras explicativas inscritos en la presente investigación son en su mayoría producto de la experiencia académica y profesional y de la síntesis personales; empero, como toda aseveración, propuesta teórica o hipótesis, pueden ser del todo discutibles, sustituidos o perfeccionados. Luego entonces, compartamos algunas invitaciones a la reflexión final.

En definitiva, la actual sociedad internacional se desenvuelve, transita y vive en una época de transición, precisamente en el tiempo y el espacio donde se conjugan el fin de un siglo caótico, la conclusión de un milenio desconcertante con enormes avances y grandes retrocesos, y el inicio 
de un tercer milenio que amenaza ser incierto, paradójico y a contracorriente de los ideales de desarrollo, derecho, equidad y justicia que han acompañado al hombre desde los inicios de su larga travesía por el camino de la historia. Ciertamente, nunca como ahora, sumidos en este amplio espectro de la denominada era de la globalidad, se habían mostrado tan patentemente los vínculos que ligan los problemas del desarrollo de la comunidad de Estados y naciones, con los del derecho, la política y las relaciones internacionales, situadas éstas en la plena manifestación de una dicotomía dialéctica: cooperación y conflicto.

Hoy día es un hecho innegable que los procesos actuales del sistema internacional y el fenómeno de la globalización de la sociedad moderna influyen de manera determinante en la naturaleza, concepto, fundamento, técnica, objeto, contenido, extensión y diversificación de la ciencia del derecho internacional, e incluso han llegado a jugar un papel fundamental en el redimensionamiento de su función normativa y regulatoria del mundo en que vivimos. Empero, una vez establecido, el derecho internacional ejerce acción recíproca hacia las relaciones y la política internacionales y hacia el propio proceso globalizador, y no en pocas ocasiones ordena, atempera, limita y condiciona su comportamiento. Ésta es la realidad, la tarea y el reto que tiene ante sí y ante un mundo que no acaba de ordenarse, el derecho internacional actual.

Aunque las relaciones internacionales penales abarcan un periodo más o menos largo en la historia contemporánea, ha resultado relevante abordar en nuestra investigación los procesos y casos significativos de la segunda posguerra a la fecha, en virtud de que en los últimos treinta años se han experimentado profundos cambios tanto en la estructura como en el contenido y funcionamiento del derecho internacional general y penal, de tal suerte que el sistema jurídico tradicional se ve sometido, cada vez con más fuerza, al fenómeno de la mundialización, así como a la discusión y cuestionamiento por parte de las políticas exteriores de los Estados, a la influencia de las fuerzas transnacionales y supranacionales, al impacto de los bloques político-económicos, y a las aspiraciones e intereses nacionales e internacionales. Ello incluye también el relevante papel que juega en los últimos tiempos el individuo como sujeto pleno y reconocido del derecho internacional penal.

Aunque todavía se ubican en la incipiencia y en el nivel del prolegómeno, el derecho internacional penal y la justicia penal internacional son parte insustituible del orden jurídico en transición que domina las relacio- 
nes internacionales, transnacionales y supranacionales. Constituyen ambos un subsistema jurídico especial, que se diferencia de los sistemas penales nacionales por su naturaleza, por la materia que regula, por los sujetos jurídicos y por los métodos de formación de normas y de su realización. Consideramos también que el derecho internacional penal es diferente y no es parte de un sistema de derecho penal nacional, ya que el objeto sobre el que recae su acción son las relaciones penales internacionales, es decir, las relaciones que tienen por principales sujetos a los Estados, a las naciones en lucha por su independencia, a las organizaciones internacionales, al crimen organizado, a las policías internacionales, a las minorías y grupos étnicos, y, entre otros más, a los individuos cuando se trata de la violación de sus derechos humanos o cuando asumen el papel de delincuentes o criminales del orden internacional.

Existe realmente una gradual extensión de los delitos internacionales, fuera de la esfera directa o indirecta del Estado (homicidios, trata de esclavos, privaciones de libertad, tortura, terrorismo, segregación, confinamiento) donde podemos observar una ampliación vacilante de los "principios generales de derecho penal reconocidos por las naciones civilizadas". El alcance y el grado de aceptabilidad de tales delitos universales dependerá de la amplitud en que sean considerados como tales en los códigos penales internacionales y en los de las diversas naciones. Por otra parte, en la evolución de los principios que rigen la jurisdicción penal nacional, y en particular los límites de la extraterritorialidad, ha habido progresos de importancia que llegan a las raíces mismas del concepto del delito. En general, las unidades estatales que habían sostenido férreamente su jurisdicción y potestad soberana, no sólo sobre sus nacionales, sino sobre los extranjeros en ciertos delitos mayores que van contra la seguridad del Estado, han comenzado a trasladar parte de esta competencia exclusiva a instancias jurisdiccionales supraestatales como los tribunales criminales ad hoc, las cortes regionales sobre derechos humanos y la Corte Penal Internacional.

Consideramos también que tanto por lo que hace al alcance de los delitos internacionales en sí como por lo que toca al ajuste de las jurisdicciones, los acontecimientos propios del sistema internacional de hoy día obligan a hacer una reconsideración y reclasificación como paso preliminar a la gradual internacionalización del derecho penal. Así, deberá revertirse la tendencia que en los últimos años ha buscado equiparar con la piratería ciertos delitos como el tráfico de personas, la trata de blancas, el 
narcotráfico, el comercio ilegal de armas, entre muchas otras conductas ilícitas, pues se trata de cuestiones muy diferentes de facto y de jure. Caso similar lo tenemos en materia de genocidio y etnocidio, donde todo tiende a equipararse al concepto de "crímenes contra la humanidad" adoptado en la Carta de Nuremberg y por los subsecuentes juicios y procesos contra criminales de guerra alemanes, japoneses, yugoslavos o ruandeses.

Es importante observar cómo continuamente se incorporan a la agenda actual del derecho internacional penal y del derecho internacional de los derechos humanos, una serie de materias nuevas y de casos especiales que resultan de la dinámica propia de la sociedad internacional. Hoy se busca, en esencia, la investigación y estudio de situaciones y hechos concretos relevantes que permitan establecer la relación de validez entre el ordenamiento internacional penal vigente y los derechos humanos a escala mundial y las nuevas exigencias sociales, así como la comprensión del proceso que desarrolla la propia comunidad de Estados, naciones, organismos e individuos para producir y renovar normas, principios y procedimientos jurídico penales y humanitarios que reflejen sus necesidades prioritarias de seguridad y de no violencia, delito y crimen en los órdenes político, social, económico, cultural, científico y tecnológico.

La sociedad en proceso de globalización —esencialmente la sociedad civil internacional - comienza a reclamar la existencia de un nuevo orden jurídico penal internacional, donde se inscriba y funcione un esquema eficiente de justicia penal internacional, lo que necesariamente descansaría en el derecho internacional existente hoy día, pero con un considerable incremento de normas nuevas, con un razonamiento y una adecuación de las normas antiguas, y con una ampliación del contenido de justicia, equidad y ética. El derecho y la justicia internacional penal constituyen elementos cada vez más necesarios de todo el orden mundial contemporáneo. Ciertamente, lo justo en el derecho de gentes no es el único, o el factor más significativo de la estructura y funcionamiento del sistema internacional y supranacional, pero el derecho y la justicia son factores sin los cuales no pueden conjugarse los demás elementos.

Los países medianos tienen una función muy importante en la formulación del derecho internacional penal y en el afianzamiento de la justicia penal internacional. Su entusiasmo, la noción de responsabilidad en esa tarea que les ha comprometido en los últimos treinta años los hace factores imprescindibles. Se requiere por tanto una coordinación inteligente de 
sus inquietudes y esfuerzos, imponiéndose asimismo una adecuada preparación de sus juristas e internacionalistas, de sus tomadores de decisiones, de sus voceros, de sus delegados ante conferencias, convenciones y organismos internacionales de interés fundamental, como lo es el caso de la Corte Penal Internacional, las Cortes de Derechos Humanos y todo el cúmulo de instancias y tareas bilaterales y multilaterales presentes y futuras.

Es importante para el gobierno de México alejar actitudes prejuiciosas y desarrollar criterios de Estado pragmáticos y objetivos, al decidir sobre los alcances y el papel que habrá de desempeñar el órgano responsable de la aplicación del derecho internacional penal, en este caso el denominado Tribunal Penal de Roma, para profundizar verdaderamente el estudio y conocimiento de su Estatuto, coadyuvando así a superar las diferencias que hasta hoy impiden su completa ratificación, implementación y funcionamiento operativo. En este sentido, habrá que aprovechar la propia dinámica de la globalización y encaminarla hacia la aceptación generalizada de este órgano colegiado supranacional de jurisdicción obligatoria. Desde otra perspectiva, este asunto se inscribiría también en el proceso de reforma de la ONU, particularmente, del sistema judicial internacional vigente, encabezado por la Corte Internacional de Justicia y su Estatuto.

En la búsqueda de un nuevo orden jurídico penal internacional en el contexto de una sociedad en constante y asombrosa mutación, es conveniente y muy necesario establecer amplios y variados mecanismos procesales, casi ausentes en el derecho internacional general y en la rama internacional penal de nuestros días. Avances en este sentido pueden observarse a través de las actuaciones jurídicas de la Corte Europea de Derechos Humanos y aun de su equivalente local, la Corte Interamericana de Derechos Humanos, que de alguna manera están sentando las bases de lo que rudimentariamente podríamos denominar el "derecho procesal internacional".

Los juristas, los internacionalistas y otros estudiosos de otros campos del saber debemos promover el interés de los Estados, de los organismos y asociaciones y de la sociedad civil en general, en el derecho internacional penal y en la justicia penal en las relaciones internacionales. Particularmente los que hacen doctrina, crean escuela y/o influyen en la toma de decisiones jurídicas y políticas, debieran activar el conocimiento y aplicación del derecho internacional general y penal, suprimiéndole conceptualismos innecesarios y nociones anticuadas y ya inoperantes, y hacerlo 
más fácilmente conocido, pues su buena observación depende de la familiaridad con este sistema legal y también de la buena calidad de las normas penales internas e internacionales.

En el siglo XXI continuará el avance en la celebración de tratados generales o multilaterales, así como de materia penal específica como los de extradición y de ejecución de sentencias, con mayor número de adheridos; sin embargo, el problema seguirá radicando en el mecanismo que se prevea para hacerlos cumplir o para que el Estado modifique su actitud reticente. Sin estar en contra de las formas de convencimiento pacífico (la persuasión, el buen ejemplo) y hasta cierto punto dentro del marco establecido por la cortesía internacional, puede resultar más efectivo para el respeto y eficacia de las normas incluir, en el mismo tratado, la tradicional característica del derecho: es decir, la sanción. Ésta, como medida coercitiva, es impuesta contra la voluntad del infractor de un orden, como prevención o a través de una serie de actos perjuiciosos que, en el caso del derecho internacional, particularmente de la rama penal, los mismos Estados establecen como castigo.

Por último, reflexionemos sobre la Corte Penal Internacional.

De ella consideramos que tiene el potencial de marcar un punto de viraje significativo en la forma en que la comunidad internacional ve la paz, la transición y la ejecución del derecho internacional. Su jurisprudencia, y la de los tribunales nacionales que investiguen y enjuicien crímenes de la competencia de la CPI, o que cooperen con ésta, llevará rápidamente al derecho internacional penal a un nivel de desarrollo acorde a su importancia. En un nivel empírico, la Corte llenará muchos vacíos que caracterizan el actual sistema de exigibilidad nacional, y alentará avances en el derecho interno y en la práctica, incluso fuera del ámbito del Estatuto como tal.

La Corte proporcionará a los Estados un foro imparcial al cual entregar individuos en situaciones en que pudieran guardar reticencias para extraditarlos a otro Estado, o bien, un foro de consenso, que ayude a resolver tensiones que surjan de una situación en la que una cantidad de jurisdicciones afectadas concurrieren por un acusado determinado; o es también posible que la CPI reduzca la tentación de los Estados de asumir acciones unilaterales de imposición agresivas. A través de estos efectos positivos en las relaciones internacionales, los Estados que entreguen un acusado podrán evitar alternativas políticas difíciles y la presión interna- 
cional, a la vez que prometer justicia a las víctimas y asegurar al acusado un juicio que mantenga las normas más elevadas del debido proceso.

Por último - y esto lo debieran tomar muy en cuenta los Estados como México, que están examinando la ratificación e implementación del Estatuto para habilitar su sistema constitucional y legal- la ventaja de flexibilidad jurisdiccional ofrecida por la Corte Penal Internacional es muy real a la luz de una buena cantidad de incidentes internacionales que involucran conflictos jurisdiccionales que han atraído la atención del mundo entero en los años recientes.

\section{BIBLIOGRAFÍA}

ANTOLISEIS, Francisco, Manual de derecho penal. Parte general, Bogotá, Editorial Themis, 1988.

BAssiouni, M. Ch., International Extradition and World Public Order, Madrid, Fontamara, 1994.

—, "The History of the Draft Code of Crimes Against the Peace and Security of Mankind", 27 ISR, L. Rev., Nueva York,1-21, UNO, 1993.

BATTA, Víctor, “Injusticia y frustraciones legítimas. Terrorismo, preocupación mundial", El Financiero, México, 11 de marzo de 1996.

BouZAT, Pierre y PINATEL, Jean, Traité de dru pénal et de criminologie, deuxiéme edition, París, Pierre Libraire Dalloz, 1970.

BRoOMHALL, Bruce, La Corte Penal Internacional: visión general, y la cooperación con los Estados, traducido por la Aprodeh, LLB University of British Columbia, 1996.

Carrancá y Trujillo, Raúl, Derecho penal mexicano. Parte general, México, Porrúa.

Cortés IBARRA, Miguel Ángel, Derecho penal. Parte general, México, Cárdenas Editor y Distribuidor, 1987.

Cuello Calon, Eugenio, Derecho penal. Parte general, Barcelona, Bosch, vol. I, 1975.

FIERRO, Guillermo, La Ley penal y el derecho internacional, Buenos Aires, Depalma, 1977.

FRAIDENRAIJ, Susana, “La Corte Penal Internacional y el derecho internacional humanitario", ponencia presentada en el Seminario de Justicia Penal Internacional, Universidad Iberoamericana, campus Santa Fe, 24-28 de febrero de 2000. 
GARCÍA RAMíREZ, Sergio, Los derechos humanos y el derecho penal, México, SepSetentas-SEP, 1976.

—-, Derecho penal, México, McGraw-Hill-IIJ, 1998.

__, "Panorama de la justicia penal", La ciencia del derecho durante el siglo XX, México, IIJ-UNAM, 1998.

Garofalo, Rafael, La criminología, Madrid, La España Moderna, Alianza Universidad, 1980.

GÓMEZ-ROBLEDO VERDUZCO, Alonso, Temas selectos de derecho internacional, México, IIJ-UNAM, 1999.

- Extradición en derecho internacional. Aspectos y tendencias relevantes, México, IIJ-UNAM, 1996.

HuET, André y KoERING-Joulin, Renée, Droit pénal international, Paris, Thémis, Presses Universitaires de France, 1994.

HERNÁNDEZ PACHECO, Susana, "El derecho penal internacional y el Proyecto de la Comisión de Derecho Internacional de la ONU relativo al Estatuto de un Tribunal penal Internacional", Revista LEX, México, núm. 4, octubre de 1995.

MAGGIORI, Giuseppe, Derecho penal, Bogotá, Themis, 1971, vol. I.

MARTEnS, G., Tratado de derecho internacional, España, Fontamara, 1990, t. III.

MENDOZA BREMAUNTZ, Emma, "El delito en la óptica internacional actual", Indicador Jurídico, México, Anfictionía Unión Universitaria, vol. 1, núm. 4, mayo de 1998.

QUINTANO RIPOLLÉS, Antonio, Tratado de derecho penal internacional e internacional penal, CSIC, Instituto "Francisco de Vitoria", España, 1957 , t. II.

PalaCiOS, M. J., Derecho penal internacional y derecho internacional penal, su diferencia y reformas que se proponen a la Constitución y otras leyes, Biblioteca del INACIPE.

Seara VÁZQueZ, Modesto, Del Congreso de Viena a la Paz de Versalles, México, FCPS, UNAM, 1973.

TUNKIN, Gregory I., El derecho y la fuerza en el sistema internacional, trad. de Manuel Becerra Ramírez, México, IIJ-UNAM, 1989.

VIEIRA, Manuel, El delito en el espacio. Derecho penal internacional y derecho internacional penal, Montevideo, Editorial Fundación de Cultura Universitaria, 1969, vol. I.

VILLARREAL CORRALES, Lucinda, La cooperación internacional en materia penal, México, PAC, 1997. 